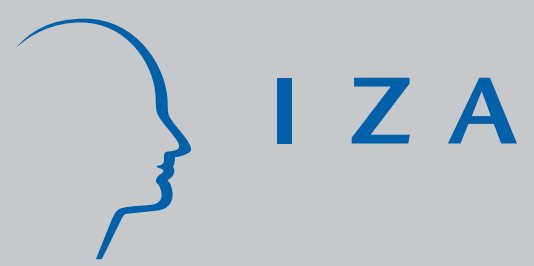

IZA DP No. 603

Income Effects from Labor Market Training

Programs in Sweden During the 80's and 90's

Thomas Andrén

Björn Gustafsson

October 2002 


\title{
Income Effects from Labor Market Training Programs in Sweden During the 80's and 90's
}

\author{
Thomas Andrén \\ University of Göteborg
}

Björn Gustafsson

University of Göteborg and IZA Bonn

Discussion Paper No. 603

October 2002

\author{
IZA \\ P.O. Box 7240 \\ D-53072 Bonn \\ Germany \\ Tel.: +49-228-3894-0 \\ Fax: +49-228-3894-210 \\ Email: iza@iza.org
}

This Discussion Paper is issued within the framework of IZA's research area Internationalization of Labor Markets. Any opinions expressed here are those of the author(s) and not those of the institute. Research disseminated by IZA may include views on policy, but the institute itself takes no institutional policy positions.

The Institute for the Study of Labor (IZA) in Bonn is a local and virtual international research center and a place of communication between science, politics and business. IZA is an independent, nonprofit limited liability company (Gesellschaft mit beschränkter Haftung) supported by the Deutsche Post AG. The center is associated with the University of Bonn and offers a stimulating research environment through its research networks, research support, and visitors and doctoral programs. IZA engages in (i) original and internationally competitive research in all fields of labor economics, (ii) development of policy concepts, and (iii) dissemination of research results and concepts to the interested public. The current research program deals with (1) mobility and flexibility of labor, (2) internationalization of labor markets, (3) welfare state and labor market, (4) labor markets in transition countries, (5) the future of labor, (6) evaluation of labor market policies and projects and (7) general labor economics.

IZA Discussion Papers often represent preliminary work and are circulated to encourage discussion. Citation of such a paper should account for its provisional character. A revised version may be available on the IZA website (www.iza.org) or directly from the author. 


\section{ABSTRACT \\ Income Effects from Labor Market Training Programs in Sweden During the 80's and 90's*}

Swedish labor market programs appear large from an international perspective, yet their consequences are not fully investigated and understood. In this paper we estimate a switching regression model with training effect modeled as a random coefficient, partitioned in an observed and unobserved component. We investigate labor market training for three cohorts during the 80 s and the beginning of the 90 s on its effect on earnings. We separate the analysis between Swedish-born and foreign-born individuals to identify differences in their responses to training. The results indicate that there is positive sorting into training. We find that the proportion of trainees having positive rewards from training was not very different from the proportion having negative rewards. This means that the results do not support the view that from efficiency considerations, too few persons were enrolled in labor market training during this period. Differences in results across cohorts can be interpreted as being caused by rapid changes in the labor market. Further, consistent with results from several previous studies we find that being young often means no positive pay-off from training, and the same is found for persons with only primary education. In conflict with what earlier studies have shown, we found that males have a better pay-off from training than females. Rewards from training were higher for foreign-born than for natives and rewards among the former vary by place of birth.

JEL Classification: J31, J38

Keywords: labor market training, non-experimental estimator, positive sorting, unobserved heterogeneity to training reward, random coefficient model

Corresponding author:

Thomas Andrén

University of Göteborg

Box 640

40530 Gothenburg

Sweden

Tel.: +46317732519

Fax: +46317731326

Email: Thomas.Andren@economics.gu.se

\footnotetext{
"We thank the Institute of Labour Market Policy Evaluation (IFAU) for financial support, and Christoph M. Schmidt, Erik Mellander and participants at IFAU seminar in autumn 2000 for useful comments. The usual disclaimer applies.
} 


\section{Table of contents}

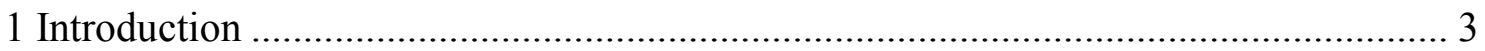

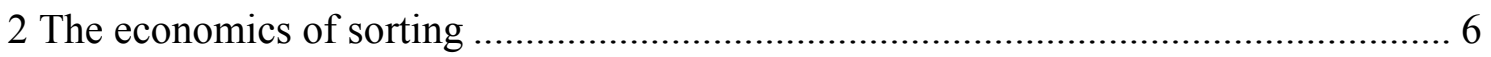

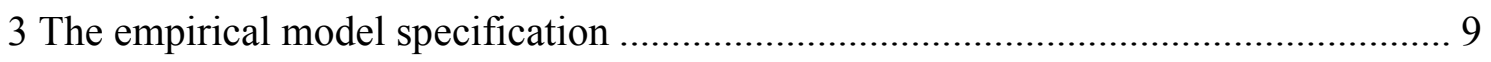

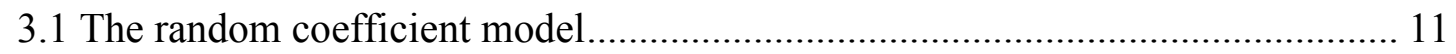

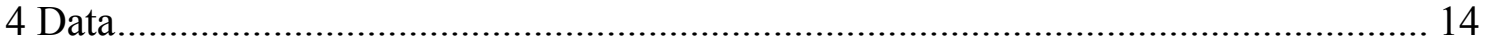

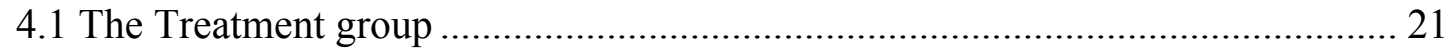

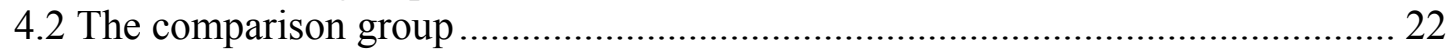

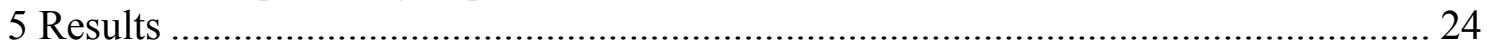

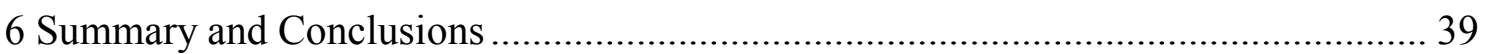

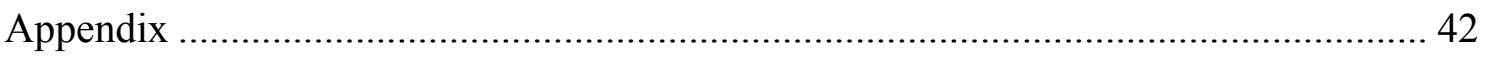

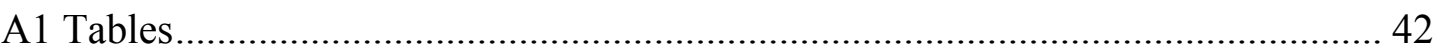

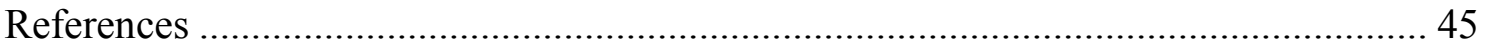




\section{Introduction}

The efforts industrialized countries make to train the unemployed and persons at risk of becoming unemployed vary dramatically. Statistics for the 90s for example (OECD 1997, 2000) show one group made up of the Czech Republic, Japan, Luxembourg, Poland and the USA where public expenditures on labor market training programs were less than $0.05 \%$ of GDP. The other extreme, with public expenditures on labor market training programs of around $0.5 \%$ of GDP or higher is found in the Scandinavian countries (Denmark, Finland and Sweden). Of the three, Sweden has the longest record of allocating massive funds to labor-market training programs. The extensive public involvement in training the unemployed in Sweden started at the beginning of the 1960s although it is possible to find even earlier efforts. During the $60 \mathrm{~s}$ the number of participants in training, henceforth trainees, increased rapidly, after which followed several examples of counter-cyclical changes.

Who receives training? This is a central issue when setting up as well as evaluating labor market training programs. The selection of trainees can be affected by the preferences of potential trainees as well as by the officials responsible for recruiting trainees, who in turn must follow instructions dictated by politicians. Starting with a potential trainee, one obvious reason for applying is the perception that the training program will improve his or her future position in the labor market when compared to not taking part in the training.

Turning to the role of placement officers, it can be noted that in Sweden public employment offices have a central role of assigning job seekers to training courses. These officers are responsible for providing information on different courses, eligibility rules, training stipends etc. The main motivation for assigning a person to labor market training is that the training should lead to a permanent job. Those eligible are mainly unemployed job seekers and individuals at risk of becoming unemployed. A person can also be eligible for other reasons. For example, political refugee status makes a foreigner eligible for training within a certain time limit after arrival.

How does training affect a person's subsequent labor market situation? Obviously training can increase the human capital of the trainee by increasing skills. Even if training only serves to preserve the human capital the effect is positive if the alternative 
(of continued unemployment) leads to decreased work-capacity. However, there can also be other mechanisms affecting the future labor market situation of a trainee.

Taking part in training might lower the person's reservation wage, making the person more likely to accept a work offer and thereby more likely to be employed. However, being involved in a training program might lead to reduced job search intensity. If this is the case, training can reduce the rate at which job offers arrive, thus reducing employment opportunities. Still another mechanism at work is that a certificate of a completed training course might act as a positive (negative) signal to potential employers. Such persons can be perceived as more (less) ambitious and therefore more (less) productive than other job-searchers.

Given the considerable resources spent on labor market training programs in Sweden, it is not surprising that training programs have been subject to several research efforts. Some authors have studied the enrolment in labor market training programs and the choice set of the unemployed [Brännäs \& Eriksson (1996), Eriksson (1997), Melkersson (1999)]. A number of studies have used non-experimental methods to evaluate the subsequent labor market performance of trainees. Some of these studies have focused on particular groups. Examples include Edin (1988) who studied training among workers displaced by a pulp plant closing in 1977, in a small town in the north of Sweden; Ackum (1991) who studied persons aged 16-24 in Stockholm in 1981; and Larsson (2000) who analyzed persons aged 20-24 that became unemployed during 1992 and 1993.

Still other studies have analyzed samples taken from the whole country and without any narrow restrictions on the age of the trainee; this is the approach taken in this paper. There are four previous studies, which in this aspect are similar to ours. First, Björklund \& Moffitt (1987) who distinguished between effects for the average and the marginal participant. Using data from the second half of the 70 s in which relatively few trainees are found, the average effects were found to be positive while the marginal impacts were found to be negative. Axelsson (1989) compared a sample of 900 persons who completed labor market training programs in 1981 with various control groups. Outcomes, one and two years after the training, were evaluated by several variables. The results show programs to have a significant positive effect on annual earnings amounting to about $20 \%$ in 1983. 
Another study is Regnér $(1993,1997)$ where the research strategy is similar but the samples larger and the econometric method of a later vintage. The study investigated training that took place during 1989 and 1990. The results indicate that training did not increase subsequent earnings of the trainee. AMS (1995) used the same econometric methods, but analyzed persons who received training in 1992 and 1994 along with control groups. It was found that subsequent earnings for the second cohort (as measured half a year later) were positive, but were negative (although not significant), for the first cohort (as measured two years after training).

Our study is inspired by the studies mentioned above but differs in a number of aspects. First, we study three different training cohorts; people who received training during the two-year periods of 1984 and 1985, 1987 and 1988, and 1990 and 1991. The macroeconomic climate varied across these cohorts as the unemployment rate in Sweden fell from a maximum of $3.5 \%$ in 1983 , reached a minimum of $1.5 \%$ in 1989 , rose to $3.0 \%$ in 1991 , and more or less exploded to $8.2 \%$ in 1993 . Thus we are able to investigate if the outcome of labor market training is affected by the macroeconomic climate, hypothesizing that positive earning effects are easier to find when there is excess demand.

Second, foreign-born persons make up a considerable proportion of all people in labor training in Sweden. We consider this fact at the outset in the sampling process and work with different samples for natives and foreign-born. This research strategy is also motivated by the fact that immigrants often are enrolled in courses other than the courses natives are enrolled in, a fact which provides a strong argument for working with different samples of natives and foreigners.

We follow the three cohorts of trainees and their control groups for three years after completed training. As the primary outcome variable we analyze annual earnings. In the econometric strategy we follow Björklund and Moffitt (1987). We estimate a switching regression model while allowing for unobserved heterogeneity with respect to the reward on training. This allows us to investigate how the reward is distributed over the individuals and their observed characteristics.

The rest of the paper is structured as follows: In the next section the theoretical framework is laid out while the empirical specification and parameters of interest are 
discussed in Section 3. The data is presented in Section 4. Section 5 presents and discusses the results and in Section 6 we sum up the conclusions.

\section{The economics of sorting}

To discuss the economics of sorting, it is convenient to define two states (treatment and no-treatment) with respect to the outcome variable of interest. We are interested in earnings and the effect on earnings from training. Hence we define two earnings equations $\left(\mathrm{Y}_{1}, \mathrm{Y}_{0}\right)$ representing the potential outcome in the post-training period for the individual:

$$
\begin{aligned}
& Y_{1}=X \beta_{1}+U_{1} \\
& Y_{0}=X \beta_{0}+U_{0}
\end{aligned}
$$

A linear decomposition with an additively separable representation is assumed, $\mathrm{X}$ being a vector of observables and $U_{1}$ and $U_{0}$ being mean zero unobservables of the individual. Subscript 1 represents the state of potential earnings if the individual participates and completes a training program and 0 the state of potential earnings if the individual chooses not to participate in a program. It is assumed that training takes place only once, during a fixed period of time, and no other training has taken place or will take place in the future. Assuming that the individual wishes to maximize the future earnings, the decision to undergo treatment is made on the basis of a net reward function:

$$
D^{*}=Y_{1}-Y_{0}-C=\alpha-C
$$

$\mathrm{D}^{*}$ is a latent variable representing the net reward from training, $\mathrm{C}$ the cost associated with training, and $\alpha$ the gross reward in terms of earnings. $\mathrm{C}$ can be thought of as some non-earnings related considerations that are relevant to the decision to undertake treatment such as tuition, stigma, distance to training center etc. When $\mathrm{C}=0$ the model coincides with the so-called Roy-Model (cf. Roy, 1951 and Heckman and Honoré, 1990) where an individual's decision to participate in training is a function of 
potential earnings only. ${ }^{1}$ In general, costs are relevant and include variables beside those included in $\mathrm{X}$, capturing differences in costs across individuals.

To specify the model further, we formalize the reward and the cost. A general formulation of the model would allow for observed and unobserved heterogeneity in both the rewards and costs associated with training. It is therefore natural to define separate behavioral equations for rewards and costs both of which include observed and unobserved components:

$$
\begin{array}{ll}
\text { Reward: } & \alpha=\mathrm{Z} \gamma+\varepsilon_{\alpha} \\
\text { Cost: } & \mathrm{C}=\mathrm{W} \delta+\varepsilon_{\mathrm{c}}
\end{array}
$$

The unobserved component of the reward equation (3) is defined as the difference between the residuals of the state specific earnings equations $\left(\varepsilon_{\alpha}=U_{1}-U_{0}\right)$ and from (2), (3) and (4), the unobserved component of the decision function (D*) is the difference between the unobserved components in (3) and (4) $\left(\varepsilon=\varepsilon_{\alpha}-\varepsilon_{c}\right)$. The full model is now defined and we have access to three behavioral components. The behavioral terms $\left(\mathrm{U}_{1}, \mathrm{U}_{0}, \varepsilon\right)$ are assumed to be independent of the exogenous variables in the model, with variances $\left(\sigma_{j}^{2}, \sigma_{\varepsilon}^{2}\right)$ and covariances $\left(\sigma_{i j}\right)$ for $i, j=1,0$. The covariances of the pairs $\left(\varepsilon, \mathrm{U}_{1}\right),\left(\varepsilon, \mathrm{U}_{0}\right)$ are denoted $\sigma_{1 \varepsilon}$ and $\sigma_{0 \varepsilon}$. The individual's decision to participate is based on perfect foresight of future net reward. That is if $\mathrm{D}^{*}$ is positive the individual will participate in training. In the opposite case, no training will take place for the individual. Relaxing this assumption by assuming that only the expected value of the net reward is known by the individual would not change the reduced form of the decision rule, although $\varepsilon$ would not include $\mathrm{U}_{1}$ and $\mathrm{U}_{0}$.

To discuss the economics of sorting into the two states we will refer to $U_{1}$ and $U_{0}$ as state-specific skills [Heckman and Honoré (1990), Vella et al. (1998)]. When $\sigma_{10}<0$ the state-specific skills are negatively correlated and we have a comparative advantage structure. That is, on average those who perform relatively well with the treatment will perform relatively less well without the treatment. When $\sigma_{10}>0$ the state-specific skills are positively correlated and we have a hierarchical structure, where on average those individuals who perform well in one state, also perform relatively well in the other state.

\footnotetext{
${ }^{1}$ This model also goes under the name the Neyman-Fisher-Cox-Roy-Quandt-Ruben model, especially at the University of Chicago.
} 
The conditional expectations of the unobserved components of the potential earnings functions are of special interest. If $\mathrm{E}\left[\mathrm{U}_{\mathrm{i}} \mid \mathrm{Z}, \mathrm{W}, \mathrm{D}=\mathrm{i}, \mathrm{i}=1,0\right]>0$, where $\mathrm{D}$ is an indicator that takes the value 1 when training take place and 0 otherwise, we say that the selection is positive. The conditional expectations of the state specific residuals can be decomposed into two parts:

$$
\begin{aligned}
& E\left[U_{1} \mid Z, W, D=1\right]=\frac{\sigma_{1 \varepsilon}}{\sigma_{\varepsilon}^{2}} E[\varepsilon \mid \varepsilon>W \delta-Z \gamma] \\
& E\left[U_{0} \mid Z, W, D=0\right]=\frac{\sigma_{0 \varepsilon}}{\sigma_{\varepsilon}^{2}} E[\varepsilon \mid \varepsilon<W \delta-Z \gamma]
\end{aligned}
$$

with $\sigma_{1 \varepsilon}=\sigma_{1}^{2}-\sigma_{10}-\sigma_{1 \mathrm{c}}$ and $\sigma_{0 \varepsilon}=\sigma_{01}-\sigma_{0}^{2}-\sigma_{0 \mathrm{c}}$. The expectations on the right hand sides of (5) and (6) have fixed signs. In (5) the expectation is always positive and in (6) it is always negative. ${ }^{2}$ With that in mind, it is the covariances that determine the signs of the conditional expectations on the left. The signs cannot be determined from the theoretical model and become therefore an empirical question. The sizes and signs of $\sigma_{1 \varepsilon}, \sigma_{0 \varepsilon}$, and $\sigma_{10}$ discussed above identify three different structures (Willis, 1986).

We consider the case where the unobserved cost component is irrelevant or uncorrelated with the state skills $\left(\sigma_{1 \mathrm{c}}=\sigma_{0 \mathrm{c}}=0\right){ }^{3}$ The first structure is the positive hierarchical sorting characterized by $\sigma_{1}^{2}>\sigma_{10}>\sigma_{0}^{2}$, which is equivalent with $\sigma_{1 \varepsilon}>0$ and $\sigma_{0 \varepsilon}>0$. Those who receive training are those who are drawn from the upper portion of the distribution of the potential earnings in state 1, while those who do not enter training are those who are drawn from the lower portion of the distribution of the potential earnings in state 0 . In this state we have a positive selection into training and negative selection into non-training.

The second structure is the negative hierarchical sorting characterized by $\sigma^{2}{ }_{1}<\sigma_{10}<$ $\sigma^{2}{ }_{0}$ which corresponds to $\sigma_{1 \varepsilon}<0$ and $\sigma_{0 \varepsilon}<0$. This is the opposite case of the previous structure. Negative hierarchical sorting is usually of little empirical importance.

The third structure is the non-hierarchical sorting which occurs when $\sigma^{2}{ }_{1}>\sigma_{10}$ and $\sigma_{0}^{2}>\sigma_{10}$, which corresponds to $\sigma_{1 \varepsilon}>0$ and $\sigma_{0 \varepsilon}<0$. In this structure the sign of $\sigma_{10}$ can

\footnotetext{
${ }^{2}$ This is true only when the selection equation has a residual with a positive sign. When a negative sign is attached to the residual the signs of the conditional expectations switch (ie. $D^{*}=Z \gamma+\varepsilon$ vs. $D^{*}=Z \gamma-\varepsilon$ )

${ }^{3}$ In the empirical analysis we impose the same assumption in order to simplify the estimation. Hence the discussion is directly linked to the model that is estimated.
} 
be either positive or negative. The signs of the covariances between state and selection imply a positive selection into both training and non-training. In general, this case applies when $\sigma_{10}$ is sufficiently small or if the scopes of the state-specific skills are about the same. The structure indicates that a person who enters state 1 would have had a higher reward in doing so as opposed to the alternative, while those who enter state 0 would be better off there as opposed to the alternative. This implies that the selection makes the groups above average in their state specific outcome distribution. ${ }^{4}$ In general the non-hierarchical sorting implies that there is more than one distinct ability factor and that the direction of the ability bias is uncertain (Willis, 1986).

\section{The empirical model specification}

Most of the empirical literature on evaluating governmental training programs focuses on mean effects and, in particular, on the mean direct effect of treatment on those who receive training [Heckman et al. (1998)]. In this paper we use the standard index sufficient method of the prototypical selection model formulated by Björklund and Moffitt (1987) so that the individual reward from training can be identified, and allowed to be unique for each individual [Heckman et. al. $(1985,1986)]$. This approach to the selection problem allows for selection on unobservables, which is an important motivation for the choice of estimator since selection into training to a large extent is determined by the ambition of the unemployed. ${ }^{5}$ Ambition is usually something that is unobserved and finding a good instrument for it would require unique data that is not at hand.

\footnotetext{
${ }^{4}$ The state specific outcome distributions are hypothetical income distributions from which the treated and untreated take their income. The hypothetical distributions do not pertain only to those in the analysis but are complete and dense distributions. It is therefore the case that the analysed group does not completely cover its state specific income distribution but only a part of it. In the case of positive selection the group is therefore located on the right upper part of the distribution.

${ }^{5}$ Eriksson (1997) carried out an informal telephone interview with Swedish officials and found that in the contact between the administrator and unemployed individuals, ambition and motivation of the unemployed were important for recruitment to a training program. Åtgärdsundersökning (1998, AMV) interviewed individuals who participated in a program in 1997. This survey showed that $60 \%$ of the participants took the initiative to participate in the training program. The unemployed person has the possibility to inform himself about different courses and programs from ring binders, billboards, and computer terminals available at the employment office. The participant's own involvement in seeking information has played the most important role in the recruitment of participants to programs. The administrator's role is more important for foreign-born (non-Nordic) in their decision to participate.
} 
If we adopt the separability assumption mentioned earlier with a linear restriction in the parameters we may form the observed Y:

$$
\mathrm{Y}=\mathrm{DY}_{1}+(1-\mathrm{D}) \mathrm{Y}_{0}
$$

By inserting (1) into (7) we obtain:

$$
\mathrm{Y}=\mathrm{X} \beta_{0}+\mathrm{D}\left[\mathrm{X}\left(\beta_{1}-\beta_{0}\right)+\left(\mathrm{U}_{1}-\mathrm{U}_{0}\right)\right]+\mathrm{U}_{0}
$$

This gives us the two regimes switching regression model (Quandt, 1972). The term multiplying $\mathrm{D}$ is the gain from the program and $\mathrm{D}$ is the observed binary analogue of the latent continuous variable $\mathrm{D}^{*}$. The gain has two components. The first component, $X\left(\beta_{1}-\beta_{0}\right)$, is the gain from the average person with characteristics $X$ in the population. This term is the so-called experimental treatment average, and would be the treatment effect in case of a social experiment (i.e. if the selection to training would have been random) [(Heckman et. al 1996), (Heckman, 1990)]. Typically this parameter is of limited interest in policy analysis since it constitutes the average gain for a person taken randomly from the population, which is a group that doesn't coincide with the target population of labor market programs. The second component, $\mathrm{U}_{1}-\mathrm{U}_{0}$, is the idiosyncratic gain for a particular person. This component will be zero if agents do not know their gain or do not act on it. The best forecast would then be zero and no additional effect due to self-selection would be present. This two-component effect is non-standard in conventional econometrics since it combines the "structural" effect, $X\left(\beta_{1}-\beta_{0}\right)$, with a stochastic effect (i.e. the change in the unobservables, $\mathrm{U}_{1}-\mathrm{U}_{0}$ ). With this set-up we can construct three parameters that usually are estimated in the literature. The effect of the treatment on the treated (9), the effect of the treatment on the non-treated (10) and the average treatment effect (11) respectively:

$$
\begin{aligned}
& E\left[Y_{1}-Y_{0} \mid X, D=1\right]=X\left(\beta_{1}-\beta_{0}\right)+E\left[U_{1}-U_{0} \mid X, D=1\right] \\
& E\left[Y_{1}-Y_{0} \mid X, D=0\right]=X\left(\beta_{1}-\beta_{0}\right)+E\left[U_{1}-U_{0} \mid X, D=0\right] \\
& E\left[Y_{1}-Y_{0} \mid X\right]=X\left(\beta_{1}-\beta_{0}\right)+E\left[U_{1}-U_{0} \mid X\right]
\end{aligned}
$$

All three estimators give the same results when $\mathrm{E}\left[\mathrm{U}_{1}-\mathrm{U}_{0} \mid \mathrm{X}, \mathrm{D}\right]=\mathrm{E}\left[\mathrm{U}_{1}-\mathrm{U}_{0} \mid \mathrm{X}\right]=$ 0 . This can happen only if $U_{1}=U_{0}$ or if agents either do not know $U_{1}-U_{0}$ or do not act 
on it. If they are the same it means that a change in one state will result in the exact same change for the individual in the other state. This implies that when we condition the difference on $\mathrm{X}$, everyone with the same $\mathrm{X}$ has exactly the same treatment effect. We think this is an unnecessary restrictive assumption and therefore allow for idiosyncratic gain in the model.

\subsection{The random coefficient model}

In order to account for the unobserved heterogeneity, one needs to make a distributional assumption for the idiosyncratic gain. If no such assumption is made, the individual gain will not be identified and only the mean sum of the two components could be estimated. We separate the reward from training from the cost of training. The selection rule then says that when the reward exceeds the cost, the individual chooses to participate in training. Formally we may express the model in the following way:

$$
\begin{array}{ll}
Y=X \beta+\alpha+u & \text { when } \mathrm{D}=1 \\
Y=X \beta+u & \text { when } \mathrm{D}=0
\end{array}
$$

$$
\begin{array}{ll}
\text { Reward: } & \alpha=Z \gamma+\varepsilon \\
\text { Cost: } & C=W \delta
\end{array}
$$

The selection rule: $D=\left\{\begin{array}{lll}1 & \text { iff } & D^{*}=\alpha-C>0 \\ 0 & \text { iff } & D^{*}=\alpha-C<0\end{array}\right.$

Each state is allowed to have its own error term with a separate variance, and free correlation between the choice equation and the two states. In the training state the unobserved component ( $\left.U_{1}\right)$ is represented by $u+\varepsilon$, while in the non-training state the unobserved component ( $\left.U_{0}\right)$ is represented by $u$ alone. We do not allow for any unobserved heterogeneity with respect to cost, primarily to decrease the complexity of the model, but also since our focus is on the heterogeneity to rewards. ${ }^{6}$ In this paper we will estimate a random coefficient model using maximum likelihood technique. The problem is therefore to define the contribution to the likelihood for each individual. 
Since the data is bivariate in nature, we start by making use of two marginal bivariate density functions, $f\left(U_{1}, \varepsilon\right)$ and $f\left(U_{0}, \varepsilon\right)$, using one density for each state. The likelihood function for this model is therefore:

$$
\begin{aligned}
& L=\left[\int_{W \delta-Z \gamma}^{\infty} f\left(U_{1}, \varepsilon\right) d \varepsilon\right]^{D}\left[\int_{-\infty}^{W \delta-Z \gamma} f\left(U_{0}, \varepsilon\right) d \varepsilon\right]^{1-D} \\
& =\left[f(u+\varepsilon) \underset{W \delta-Z \gamma}{\int} f(\varepsilon \mid u+\varepsilon) d \varepsilon\right]^{D}\left[f(u) \int_{-\infty}^{W \delta-Z \gamma} f(\varepsilon \mid u) d \varepsilon\right]^{1-D}
\end{aligned}
$$

Since $U_{1}=u+\varepsilon$ and $U_{0}=u$ the two marginal densities contain only two unique stochastic components which makes it possible limit the distributional assumption to one bivariate density. The two behavioral components used in the estimation have the following joint distribution:

$$
\left(\begin{array}{l}
\varepsilon \\
u
\end{array}\right) \sim N\left(0, \quad\left(\begin{array}{cc}
\sigma_{\varepsilon}^{2} & \sigma_{\varepsilon u} \\
\sigma_{u \varepsilon} & \sigma_{u}^{2}
\end{array}\right)\right)
$$

With this assumption it is possible to derive the components to be used in the likelihood function namely, $\sigma_{10}, \sigma_{1 \varepsilon}, \sigma_{0 \varepsilon}, \sigma_{1}^{2}, \sigma_{0}^{2}$ and $\sigma_{\varepsilon}^{2}$. Few identifying restrictions have been applied. One important restriction is the parameters in the reward equation. In order to identify the variance of the reward $\left(\sigma_{\varepsilon}^{2}\right)$ we have normalized $\gamma=1$, in the selection equation (i.e. in $f(\varepsilon \mid u)$ and $f(\varepsilon \mid u+\varepsilon)$ ) while allowing it to be unrestricted in the wage equation (i.e. in $f(u)$ and $f(u+\varepsilon))^{7}{ }^{7}$ This works if we have at least one variable in $Z$ that is not in $W$. This model does not formally require an exclusion restriction (instrument) between the selection equation and the earnings equation. That the exclusion restriction can be useful in any case is shown by Monte Carlo studies finding that the estimator performs poorly when exclusion restrictions are not imposed. ${ }^{8}$ No other restrictions

\footnotetext{
${ }^{6}$ Björklund and Moffitt (1987) estimate this model allowing for unobserved heterogeneity with respect to cost as well. When they tested if this contributed to the model they received insignificant test results indicating that the unobserved cost components were of minor importance in their case.

${ }^{7}$ See Björklund and Moffitt (1987). The technique is replicated from their study.

${ }^{8}$ It is important, however, that the instrument that constitutes the exclusion restriction is good in the sense that it is correlated with the selection process but uncorrelated with the outcome variable. It can be hard to find good instruments unless one specially designs a survey for this purpose.
} 
have been applied. The treatment on the treated and the corresponding variance is therefore defined as:

$$
\begin{aligned}
& E[\alpha \mid D=1, Z \gamma, W \delta]=Z \gamma+\sigma_{\varepsilon} \lambda\left((W \delta-Z \gamma) / \sigma_{\varepsilon}\right) \\
& V[\alpha \mid D=1, Z \gamma, W \delta]=\sigma_{\varepsilon}^{2}\left[1-\lambda\left((W \delta-Z \gamma) / \sigma_{\varepsilon}\right)\left[\lambda\left((W \delta-Z \gamma) / \sigma_{\varepsilon}\right)-(W \delta-Z \gamma) / \sigma_{\varepsilon}\right]\right.
\end{aligned}
$$

with $\lambda($.$) being the inverse of Mills ratio. { }^{9}$ The variable specifications pertaining to the different equations are important. The variables explaining the outcome equation are standard, namely age, gender and education. The ambition has been to have the specification as parsimonious as possible yet including what is relevant, and accessible. The reward to training is explained by the same observed factors as in the outcome equation. We find no reason to include anything there that was not in the earnings equation. The cost equation is more complicated. It should include non-earnings related factors such as preferences and foregone income etc, which are not included in our data set. It could be argued that ability to learn decreases by age and therefore induces negative preferences for training. Preference towards training might also differ by gender, in the sense that women and men respond differently to training. Distance to the training center is another factor that might induce a cost. Living in a big city region might create the feeling of being closer to the training center, compared to living outside the city.

Heckman et al (1999) argue that this model emphasizes changes in the opportunity costs, i.e., foregone earnings, as the major determinant of participation in training programs. They show evidence that suggests that changes in labor force status predict participation in programs. We therefore include number of days of unemployment the year before training as a factor. The variables used as exclusion restrictions (instruments) are big-city region and previous unemployment. Intuitively we feel that living in a big city region is correlated with the selection process while the correlation with the outcome variable is unclear. When looking at the descriptive statistics we see that the proportion living in big city region is larger for those participating in a training program compared to those who do not, which implies that it is more likely that such a

\footnotetext{
${ }^{9}$ See Maddala (1983) and Greene (1993) for further information about the mean and variance of the normal truncated distributions.
} 
person goes to training. In the same way we are convinced that the earlier unemployment situation is correlated with the selection process, and we have evidence mentioned above that such is the case in the US. In the data section it will be apparent that we have a pre-training dip in earnings in our sample, which therefore further confirms the relevance of the variable in our case. When looking at correlation measures among the variables for participation, living in big city region and earlier unemployment, we find significant correlation coefficients. When, on the other hand, we look at the correlations between the earnings variables and the instruments we find insignificant correlation coefficients. This situation holds true over time as well.

The foreign-born group has an extended variable specification in both the earnings and the reward equation. Country of origin and number of years in Sweden play an important role in the determination of the individual's success in the labor market and therefore also on the reward and earnings of participating in a training program. We have therefore included such variables to control for any observed differences related to these factors.

\section{Data}

We have access to a register database (SWIP) that constitutes a stratified random sample of the population living in Sweden. ${ }^{10}$ It is stratified into two parts: the first is a $1 \%$ sample of the Swedish-born population and the second is a $10 \%$ sample of the foreign-born population. The stratified random sample was drawn by Statistics Sweden using population files from 1978. The individuals drawn at that initial year were followed over time with repeated yearly cross-sections. To each consecutive year a supplement of individuals were added to each cross-sectional unit to adjust for migration and newly born; the intention being to make each and every stratified crosssection representative for the Swedish population with respect to each stratum.

Descriptive statistics presented in Tables $1 \mathrm{a}$ and $1 \mathrm{~b}$ show that the treatment groups for the 1984-85 cohorts consists of 490 natives and 982 foreign-born. This corresponds to a population in training programs in Sweden of 59,320 persons for these years. The

\footnotetext{
${ }^{10}$ The Swedish Income Panel (SWIP) is a register based panel data set administrated by Swedish Social Science Data Service (SSD). More information can be found at www.ssd.gu.se.
} 
1987-88 and 1990-91 samples of trainees are of similar sizes and correspond to populations in training programs of 61,420 and 57,410, respectively.

Tables 1-3 show that the gender composition among people in training programs is relatively even for all cohorts. Although there is a variation in age among the trainees, the majority (or nearly the majority) are in the interval 26 to 45 years with a mean of around 30 years for natives and slightly higher for foreign-born.

In general the trainees and non-trainees have similar characteristics, but there are a few exceptions worth mentioning. The two first cohorts of the Swedish born trainees have on average higher education than the non-trainees while this difference changes in the third cohort where the groups have similar education levels. Hence, in the beginning of the $80 \mathrm{~s}$ when the unemployment level were low, higher educated were selected (or self selected) into training to a lager extent compared to the beginning of the $90 \mathrm{~s}$ when unemployment levels were increasing. This might be a sign of a policy change in the sense that instead of reeducating people with an existing education the focus in the $90 \mathrm{~s}$ might been on further education for those with low education. Another difference that is more striking is that trainees on average have shorter earlier unemployment spells the year before training compared to the non-trainees. This indicates that those with shorter unemployment spells were selected into labor market training (by themselves or by the administrator). This difference remains the same for all three cohorts. Both education and pre-training unemployment spells are included in the model and therefore controlled for when estimating the treatment effects. 
Table 1a Descriptive statistics for the 1984/85 Swedish-born cohort

\begin{tabular}{lcccc}
\hline & \multicolumn{2}{c}{ Trainees } & \multicolumn{2}{c}{ Non-trainees } \\
\cline { 2 - 5 } & Men & Women & Men & Women \\
\hline Observations & 219 & 271 & 852 & 1156 \\
Age (mean) & 30.15 & 31.87 & 29.98 & 30.32 \\
20-25(\%) & 37 & 36 & 44 & 44 \\
26-45(\%) & 54 & 55 & 46 & 45 \\
46-55(\%) & 8 & 9 & 10 & 11 \\
\hline Region (Big city) (\%) & 32 & 28 & 27 & 23 \\
Married (\%) & 19 & 39 & 19 & 36 \\
Children 0-6 year (\%) & 12 & 25 & 12 & 23 \\
Children 7-12 year (\%) & 8 & 24 & 9 & 16 \\
\hline Education (\%) & & & & \\
Primary & 27 & 40 & 50 & 52 \\
Secondary & 58 & 50 & 46 & 37 \\
Post secondary & 15 & 10 & 4 & 11 \\
Unemployed last year (days) & 25 & 18 & 30 & 22 \\
\hline
\end{tabular}

Table 1b Descriptive statistics for the 1984/85 foreign-born cohort

\begin{tabular}{lcccc}
\hline & \multicolumn{2}{c}{ Trainees } & \multicolumn{2}{c}{ Non-trainees } \\
\cline { 2 - 5 } & Men & Women & Men & Women \\
\hline Observations & 487 & 495 & 907 & 1007 \\
Age (mean) & 33.14 & 32.73 & 34.12 & 33.64 \\
20-25(\%) & 22 & 26 & 20 & 26 \\
$26-45(\%)$ & 68 & 63 & 65 & 59 \\
46-55(\%) & 9 & 11 & 15 & 15 \\
\hline Region (Big city) (\%) & 54 & 55 & 20 & 39 \\
Married (\%) & 42 & 58 & 38 & 54 \\
Children 0-6 (\%) & 22 & 38 & 21 & 34 \\
Children 7-12 (\%) & 15 & 27 & 14 & 26 \\
\hline Education (\%) & & & & \\
Primary & 46 & 55 & 61 & 61 \\
Secondary & 49 & 39 & 36 & 31 \\
Post secondary & 3 & 6 & 6 & 8 \\
Unemployed last year (days) & 19 & 13 & 30 & 27 \\
\hline Number of years in the country (\%) & & & & \\
0-5 & 27 & 33 & 11 & 8 \\
6-10 & 20 & 18 & 28 & 22 \\
11- & 53 & 48 & 61 & 70 \\
\hline Region of birth (\%) & & & & \\
Nordic & 40 & 41 & 45 & 60 \\
Northern Europe & 9 & 8 & 9 & 9 \\
Eastern Europe & 6 & 15 & 7 & 9 \\
Southern Europe & 15 & 9 & 16 & 11 \\
Middle East & 16 & 8 & 14 & 6 \\
Rest of the world & 14 & 17 & 9 & 6 \\
\hline
\end{tabular}


Table 2a Descriptive statistics for the 1987/88 Swedish-born cohort

\begin{tabular}{lcccc}
\hline & \multicolumn{2}{c}{ Trainees } & \multicolumn{2}{c}{ Non-trainees } \\
\cline { 2 - 5 } & Men & Women & Men & Women \\
\hline Observations & 220 & 298 & 783 & 1183 \\
Age (mean) & 30.42 & 32.05 & 30.97 & 30.98 \\
20-25 (\%) & 41 & 38 & 38 & 40 \\
26-45 (\%) & 49 & 50 & 51 & 49 \\
46-55 (\%) & 10 & 12 & 11 & 11 \\
\hline Region (Big city) (\%) & 22 & 21 & 21 & 22 \\
Married (\%) & 15 & 35 & 19 & 32 \\
Children 0-6 year (\%) & 9 & 24 & 12 & 26 \\
Children 7-12 year (\%) & 7 & 23 & 8 & 15 \\
\hline Education (\%) & 28 & 31 & & \\
Primary & 62 & 46 & 54 & 30 \\
Secondary & 10 & 23 & 6 & 37 \\
Post secondary & 17 & 11 & 29 & 25 \\
Unemployed last year (days) & 17 & & & \\
\hline
\end{tabular}

Table 2b Descriptive statistics for the 1987/88 foreign-born cohort

\begin{tabular}{lcccc}
\hline & \multicolumn{2}{c}{ Trainees } & \multicolumn{2}{c}{ Non-trainees } \\
\cline { 2 - 5 } & Men & Women & Men & Women \\
\hline Observations & 514 & 448 & 937 & 1013 \\
Age (mean) (\%) & 33.23 & 34.00 & 34.96 & 34.14 \\
20-25 (\%) & 23 & 20 & 17 & 22 \\
26-45 (\%) & 66 & 66 & 69 & 65 \\
46-55 (\%) & 11 & 14 & 15 & 14 \\
\hline Region (Big city) (\%) & 53 & 46 & 45 & 37 \\
Married (\%) & 39 & 50 & 37 & 51 \\
Children 0-6 (\%) & 20 & 34 & 20 & 37 \\
Children 7-12 (\%) & 13 & 31 & 13 & 26 \\
\hline Education (\%) & & & & \\
Primary & 36 & 43 & 57 & 54 \\
Secondary & 57 & 45 & 38 & 35 \\
Post secondary & 8 & 13 & 4 & 10 \\
Unemployed last year (days) & 16 & 15 & 32 & 30 \\
\hline Number of years in the country (\%) & & & & \\
0-5 & 36 & 26 & 11 & 8 \\
6-10 & 16 & 21 & 25 & 23 \\
11- & 48 & 52 & 64 & 69 \\
\hline Region of birth (\%) & & & & \\
Nordic & 33 & 44 & 41 & 57 \\
Northern Europe & 5 & 8 & 8 & 9 \\
Eastern Europe & 9 & 17 & 10 & 11 \\
Southern Europe & 10 & 7 & 11 & 9 \\
Middle East & 26 & 8 & 17 & 6 \\
Rest of the world & 16 & 16 & 13 & 9 \\
\hline
\end{tabular}


Table 3a Descriptive statistics for the 1990/91 Swedish-born cohort

\begin{tabular}{lcccc}
\hline & \multicolumn{2}{c}{ Trainees } & \multicolumn{2}{c}{ Non-trainees } \\
\cline { 2 - 5 } & Men & Women & Men & Women \\
\hline Observations & 231 & 246 & 683 & 956 \\
Age (mean) & 31.14 & 33.71 & 31.58 & 32.63 \\
20-25 (\%) & 40 & 28 & 35 & 30 \\
26-45 (\%) & 48 & 54 & 52 & 55 \\
46-55 (\%) & 13 & 17 & 13 & 15 \\
\hline Region (city) (\%) & 20 & 28 & 25 & 26 \\
Married (\%) & 22 & 42 & 23 & 37 \\
Children 0-6 year (\%) & 15 & 26 & 11 & 26 \\
Children 7-12 year (\%) & 6 & 24 & 7 & 15 \\
\hline Education (\%) & & & & \\
Primary & 35 & 39 & 30 & 28 \\
Secondary & 55 & 54 & 56 & 56 \\
$\quad$ Post secondary & 10 & 7 & 14 & 16 \\
Unemployed last year (days) & 11 & 10 & 17 & 15 \\
\hline
\end{tabular}

Table 3b Descriptive statistics for the 1990/91 foreign born cohort

\begin{tabular}{lcccc}
\hline & \multicolumn{2}{c}{ Trainees } & \multicolumn{2}{c}{ Non-trainees } \\
\cline { 2 - 5 } & Men & Women & Men & Women \\
\hline Observations & 467 & 504 & 990 & 937 \\
Age (mean) & 33.68 & 34.22 & 34.97 & 34.97 \\
20-25 (\%) & 17 & 19 & 16 & 16 \\
26-45 (\%) & 72 & 69 & 68 & 68 \\
46-55 (\%) & 10 & 12 & 15 & 15 \\
\hline Region (Big city) (\%) & 44 & 43 & 52 & 42 \\
Married (\%) & 50 & 60 & 39 & 55 \\
Children 0-6 (\%) & 29 & 35 & 21 & 34 \\
Children 7-12 (\%) & 19 & 31 & 14 & 26 \\
\hline Education (\%) & & & & \\
Primary & 74 & 73 & 50 & 47 \\
Secondary & 23 & 23 & 38 & 40 \\
Post secondary & 3 & 3 & 11 & 13 \\
Unemployed last year (days) & 9 & 8 & 19 & 15 \\
\hline Number of years in the country (\%) & & & & \\
0-5 & 52 & 45 & 20 & 16 \\
6-10 & 16 & 15 & 19 & 17 \\
11- & 32 & 18 & 61 & 67 \\
\hline Region of birth (\%) & & & & \\
$\quad$ Nordic & 20 & 29 & 35 & 46 \\
North Europe & 4 & 6 & 8 & 9 \\
East Europe & 8 & 14 & 7 & 11 \\
South Europe & 6 & 6 & 11 & 7 \\
Middle East & 38 & 22 & 25 & 12 \\
Rest of the world & 23 & 23 & 13 & 14 \\
\hline & & & & \\
\hline
\end{tabular}


The foreign-born trainees and their comparison groups are more concentrated to the larger cities than their native counterparts. Few trainees have post-secondary education. Looking at immigrant specific variables, it can be seen that about half of the foreignborn trainees in the two first cohorts have lived in Sweden for more than a decade, while many foreign-born trainees in the third cohort are recent arrivals. Across the cohorts of foreign born there is also a shift in region of birth. People born in other Nordic countries make up a considerable proportion of the trainees in the first cohort while a large portion of people born in countries outside Europe makes up the last cohort of trainees.

Earnings is our outcome variable, and it consists of incomes from employment and self-employment and is measured on an annual basis. This means that our outcome variable captures wage effects of training as well as effects from number of hours worked. We follow trainees and their counterfactuals during a period of three years before training until three years after training.

Figure 1 shows for all cohorts, natives and foreign-born, how mean earnings have developed for trainees as well as for the comparison group. With the exception of the period of training, the curves for the treatment group and the comparison group rise until the beginning of the $90 \mathrm{~s}$ after which they decrease. This reflects the general development of real earnings in the Swedish economy during the period under study.

The curves for the native trainees and non-trainees start at approximately the same level. The curves for trainees then decrease during the period of training, and after the completion of the training period return to approximately the same level as for the nontrainees. This makes us suspect that the average training reward for natives cannot be large. Turning to foreign-born the situation is somewhat different. Trainees have considerably lower earnings than non-trainees before training, and reach approximately the same level after training. This makes us suspect that the average reward for foreignborn trainees is positive. Figure 1 also indicates the presence of Ashenfelter's dip in the pre-training earnings (Ashenfelter, 1978), which therefore leads us to believe that employment status before training could work as an indicator for selection into training. The exception is the third cohort of the foreign-born people who do not dip (or started their dip earlier, before the observation window. This situation is partly explained by the 
large number of newly arrived immigrants that apparently had little or no earnings before training.
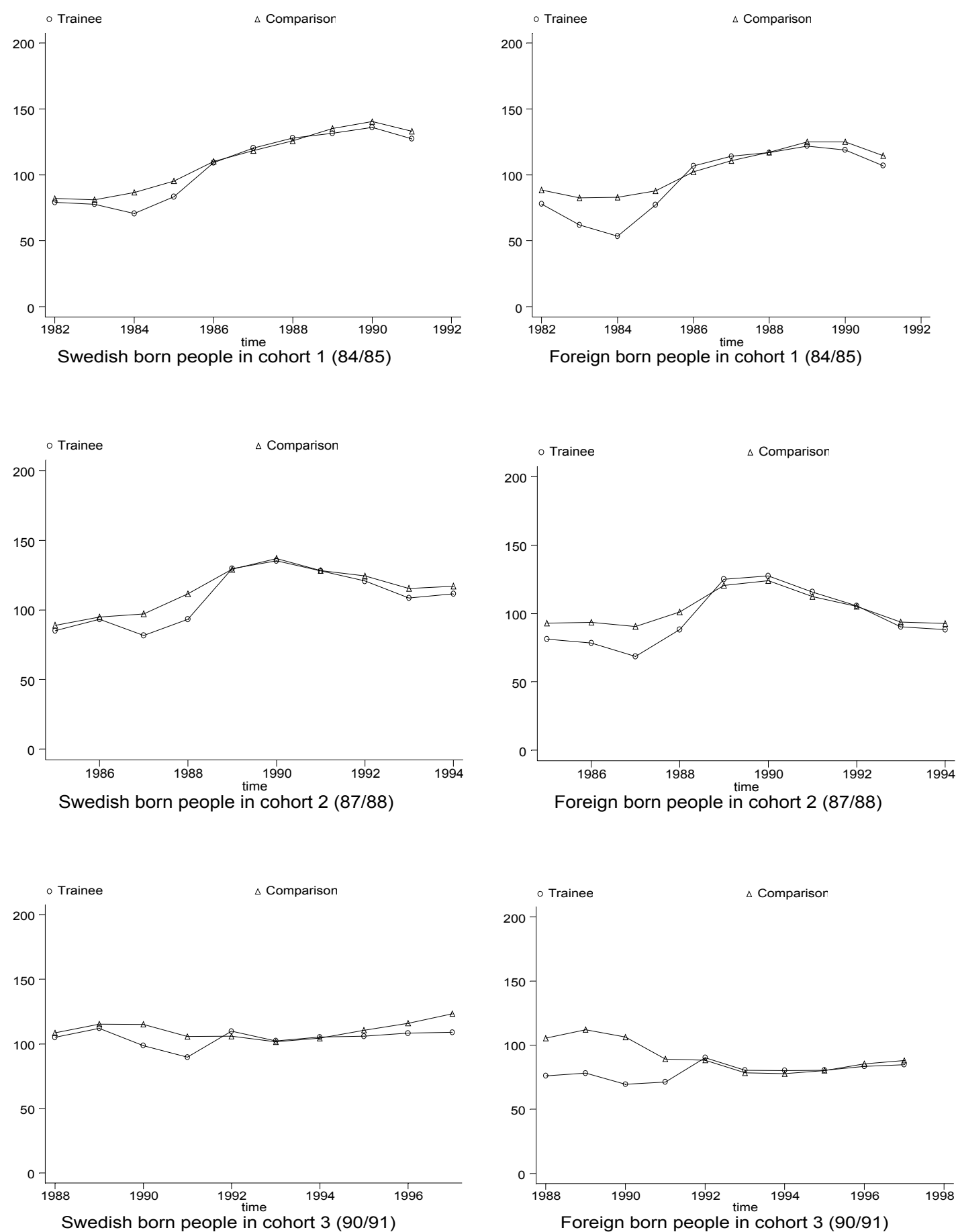

Figure 1 Earnings development over time and cohorts (earnings are deflated using 1999 as base year and given in thousands of SEK) 


\subsection{The treatment group}

As mentioned above, we analyze three different cohorts of trainees, and the first cohort was drawn from the 1984 and 1985 cross-sections of SWIP. To be able to include trainees taking courses longer than a year or courses that start one year and ends the second year, it was necessary to sample trainees from a two-year cross-sectional window and then merge the two cross-sectional samples into one. The sample of trainees for each cohort can therefore be classified into three groups. The first group consists of people who participated in a program the first year only, the second group of individuals who participated in a program the second year only, and the third group of individuals who participated in a program that started the first year and ended the second year. These individuals were controlled not to have participated in any labormarket training program three years before and three years after the two-year crosssectional window, which we refer to as the training period. ${ }^{11}$ The two following cohorts were drawn in exactly same way but from different cross-sectional years namely, $1987 / 88$ and 1990/91.

The critical question when using population files is how to identify the trainees. From the files we have information about how large of a training grant an individual received for a given year. Training grants therefore function as a flag variable, indicating whether or not a person took part in training that particular year. Since this is our only way of identifying trainees, we have no information as to whether the trainee actually completed the program. Dropouts might therefore be a source of bias in the estimates of the training effects. In order to reduce the training cohort from individuals who dropped out immediately or at the beginning of the program, we decided to truncate the sample with respect to the amount of training grant an individual received. We thought that a training grant corresponding to a four-week period would work as a lower truncation point. ${ }^{12}$ Since the official rules prescribe that only individuals aged 20 or older may participate in a program, we set the lower age limit to 20 and an upper arbitrary level at 55. The first cohort had no one older then 55 years of age, which

\footnotetext{
${ }^{11}$ When constructing the treatment group the idea is to have a group that participate in one program during a specific time period, and that no training have taken place or will take place during the follow up period. This is important when the ambition is to measure the income effect from one program.

${ }^{12}$ The truncation of the training grant reduced the number of trainees in each cohort with 4-7\%.
} 
therefore made us choose that upper age limit for all three cohorts. There are exceptions to the lower age limit, but we disregard them in this paper.

A problem with our flag-variable is that it contains two sorts of individuals. It includes individuals from labor market training programs but also individuals who have been participating in programs administrated by the Labor Market Institute (AMI). AMI is not a training program but individuals enrolled in AMI received the same kind of allowance, and since we identify the individuals from the grant received, we are not able to separate them. Fortunately, AMI individuals only comprise around $13 \%$ of the sample and the proportion stays constant during the observation window. The average schooling time for AMI participants is around 2-3 months, while a training program lasts on average around 5-6 months. This means that we reduced the AMI part proportionally more then the trainee part of the sample with the lower truncation point.

\subsection{The comparison group}

The main idea is to construct a group that is comparable to the treatment group with respect to the characteristics of the trainees. A natural group to consider is that of individuals who were unemployed during the training period but who did not participate in any training program. When constructing the comparison groups for the three cohorts we use the same observation window as for the trainees. For the first cohort we take unemployed individuals from 1984 and 1985 cross-sectional years and pool them together to one set of non-trainees. 1987/88 and 1990/91 cross-sectional years were used in the same way for the other two cohorts.

Our dataset offers information about how much unemployment insurance (UI and/or CA) a person received in a given year, and this therefore works as an unemployment indicator when we select individuals into the set of non-trainees for the three cohorts. Individuals participating in training usually have had a period of unemployment before a program may be an option. It is therefore important to have individuals with some length of unemployment in the non-treatment group. From a recent study by Okeke (2001) we know that the average waiting time before starting a training program is 3 months. This implies that around $50 \%$ of all participants have been unemployed a 
period shorter then 3 months. ${ }^{13}$ By imposing a lower truncation point for the nontrainees we will be able to move the average unemployment duration forward and thereby construct a group that looks more like the trainees with respect to this point. We decided that one month would be an accurate number for this purpose and deleted individuals with less then one month of unemployment. ${ }^{14}$

Table 4 Compensation levels in SEK per day ${ }^{15}$

\begin{tabular}{lccc}
\hline Benefit & 1984 & 1987 & 1990 \\
\hline Average UI & 239.86 & 307.28 & 402.07 \\
Maximum UI & $(300)$ & $(360)$ & $(495)$ \\
Cash Assistance & 185 & 240 & 297 \\
\hline
\end{tabular}

Source: Olli, 1996. (Nominal figures)

Compensated days per month $=\frac{(\text { Days per year }-2 * \text { number of weeks per year })}{12}=21,75$

To estimate the duration of unemployment for an individual who was entitled to unemployment insurance, we divided the total amount of unemployment insurance a person received a given year with the daily average unemployment insurance individuals in general received that particular year (see Table 4). That gives us an estimate of how many days that particular individual was unemployed that year. Dividing that number with the average number of days per month an individual could be compensated (21.75), we receive an approximation of the number of months an individual has been unemployed. If the individual was only entitled to cash assistance we divided by that figure instead. Furthermore we checked that the individuals did not participate in any training programs three years before and three years after the training period. The idea behind this was to control that none among the non-treated in fact were treated by a program in an earlier time period or participated in a program during the follow-up period when evaluating the treatment effects. This control was imposed on both the treaded and the non-treated, which therefore harmonizes the comparison. We applied the same age interval as for the trainees, i.e. only individuals aged 20-55.

\footnotetext{
${ }^{13}$ If the distribution of waiting times is skewed to the left a smaller proportion of trainees starts earlier then 3 months.

${ }^{14}$ When using a lower truncation point of 1 month around $23 \%$ of the individuals in the original sample were lost. If a truncation point of 2 months were used around $40 \%$ were lost.

${ }^{15}$ Represents the average compensation amount that particular year. The unemployment insurance covers $80 \%$ of the previous income but only up to a maximum level. The maximum level is given within parentheses. Cash assistance is paid by a fixed amount. Compensation is paid 5 days per week.
} 


\section{Results}

The estimates of the random coefficient model showing the treatment effect on earnings one year after the training are reported in Tables 5 and 6 . Some comments can be made. Starting with the earnings equation, there is hardly a pattern of coefficients being large and estimated with small standard errors in any of the six samples. However, being male not surprisingly is associated with larger earnings among natives in the first two cohorts, and college education appears to yield substantially higher earnings in the third cohort for natives as well as foreign-born. One can also observe among immigrants that certain effects of origin are significant. For example in all cases, coefficients for variables measuring origin from the Middle East and "the rest of the world", respectively, (not in another Nordic country) are negative and estimated with a relatively small standard error. In general the estimates for education are small or insignificant except for the last cohort where the estimates are large and significant. We know from the descriptive statistics that the educational level of the trainees on average was higher then for the non-trainees in the first two cohorts. In the last cohort that difference switched and the non-trainees became somewhat higher educated compared to the trainees. We also know that during the period studied the importance of having a college degree for getting a job increased, relative to having a high school degree. One reason for the large college effect might therefore be that individuals with this level of education received jobs to a larger extent.

Looking at the estimates of the reward equation, it can be noted that in many cases belonging to the youngest category (20-25) - the reference category - is associated with lower rewards than belonging to any other age category. In most cases the coefficient for the gender variable is not significant, the third cohort natives being an exception. There is a pattern of education higher than primary school leading to larger rewards in most cases. Looking at variables specific to foreign-born, there is a pattern of a residency period longer than five years leading to larger rewards than a shorter residency. Further, rewards for originating from a country other than a Nordic country the reference area - are generally positive and estimated with a relatively small standard error. 
Table 5 Model estimates for the random coefficient model one year after training ${ }^{16}$

\begin{tabular}{|c|c|c|c|c|c|c|}
\hline & \multicolumn{3}{|c|}{ Swedish-born } & \multicolumn{3}{|c|}{ Foreign-born } \\
\hline & Cohort 1 & Cohort 2 & Cohort 3 & Cohort 1 & Cohort 2 & Cohort 3 \\
\hline \multicolumn{7}{|l|}{ Earnings } \\
\hline Constant & $\begin{array}{l}4.431 * \\
(0.028)\end{array}$ & $\begin{array}{l}4.488 * \\
(0.030)\end{array}$ & $\begin{array}{l}4.360 * \\
(0.057)\end{array}$ & $\begin{array}{l}4.302 * \\
(0.074)\end{array}$ & $\begin{array}{l}4.507 * \\
(0.069)\end{array}$ & $\begin{array}{l}4.189 * \\
(0.083)\end{array}$ \\
\hline Age (26-45) & $\begin{array}{c}0.018 \\
(0.029)\end{array}$ & $\begin{array}{c}0.074 * \\
(0.030)\end{array}$ & $\begin{array}{c}0.005 \\
(0.060)\end{array}$ & $\begin{array}{c}-0.018 \\
(0.037)\end{array}$ & $\begin{array}{l}0.130 * \\
(0.041)\end{array}$ & $\begin{array}{c}0.025 \\
(0.058)\end{array}$ \\
\hline Age (46-55) & $\begin{array}{c}0.015 \\
(0.045)\end{array}$ & $\begin{array}{c}0.147 * \\
(0.046)\end{array}$ & $\begin{array}{c}0.019 \\
(0.067)\end{array}$ & $\begin{array}{c}0.071 \\
(0.059)\end{array}$ & $\begin{array}{l}0.128 * \\
(0.055)\end{array}$ & $\begin{array}{c}0.015 \\
(0.078)\end{array}$ \\
\hline Male & $\begin{array}{c}0.194 * \\
(0.027)\end{array}$ & $\begin{array}{c}0.185 * \\
(0.029)\end{array}$ & $\begin{array}{l}-0.050 \\
(0.041)\end{array}$ & $\begin{array}{l}0.126^{*} \\
(0.038)\end{array}$ & $\begin{array}{c}0.079 * \\
(0.033)\end{array}$ & $\begin{array}{c}-0.056 \\
(0.045)\end{array}$ \\
\hline High school & $\begin{array}{c}0.047 \\
(0.030)\end{array}$ & $\begin{array}{c}0.059 \\
(0.031)\end{array}$ & $\begin{array}{c}0.034 \\
(0.048)\end{array}$ & $\begin{array}{l}-0.020 \\
(0.040)\end{array}$ & $\begin{array}{c}0.022 \\
(0.035)\end{array}$ & $\begin{array}{l}-0.019 \\
(0.051)\end{array}$ \\
\hline College & $\begin{array}{l}0.100 * \\
(0.051)\end{array}$ & $\begin{array}{c}0.088 \\
(0.048)\end{array}$ & $\begin{array}{l}0.251 * \\
(0.064)\end{array}$ & $\begin{array}{c}0.035 \\
(0.079)\end{array}$ & $\begin{array}{c}0.077 \\
(0.062)\end{array}$ & $\begin{array}{l}0.428 * \\
(0.071)\end{array}$ \\
\hline \multicolumn{7}{|l|}{ Reward } \\
\hline Constant & $\begin{array}{l}-2.182 * \\
(0.131)\end{array}$ & $\begin{array}{c}-1.564 * \\
(0.135)\end{array}$ & $\begin{array}{l}-2.755^{*} \\
(0.414)\end{array}$ & $\begin{array}{l}-2.492 * \\
(0.147)\end{array}$ & $\begin{array}{l}-2.531 * \\
(0.154)\end{array}$ & $\begin{array}{c}-2.998 * \\
(0.213)\end{array}$ \\
\hline Age (26-45) & $\begin{array}{l}0.350 * \\
(0.068)\end{array}$ & $\begin{array}{c}0.021 \\
(0.088)\end{array}$ & $\begin{array}{c}0.459 \\
(0.489)\end{array}$ & $\begin{array}{l}0.346^{*} \\
(0.078)\end{array}$ & $\begin{array}{l}0.138 * \\
(0.071)\end{array}$ & $\begin{array}{l}0.400 * \\
(0.093)\end{array}$ \\
\hline Age (46-55) & $\begin{array}{c}0.687^{*} \\
(0.148)\end{array}$ & $\begin{array}{c}0.112 \\
(0.130)\end{array}$ & $\begin{array}{l}0.515 * \\
(0.218)\end{array}$ & $\begin{array}{c}0.267 \\
(0.141)\end{array}$ & $\begin{array}{c}0.141 \\
(0.134)\end{array}$ & $\begin{array}{l}0.512 * \\
(0.201)\end{array}$ \\
\hline Male & $\begin{array}{c}0.003 \\
(0.094)\end{array}$ & $\begin{array}{c}0.101 \\
(0.086)\end{array}$ & $\begin{array}{l}0.405 * \\
(0.147)\end{array}$ & $\begin{array}{c}0.103 \\
(0.093)\end{array}$ & $\begin{array}{c}0.128 \\
(0.086)\end{array}$ & $\begin{array}{l}-0.131 \\
(0.126)\end{array}$ \\
\hline High school & $\begin{array}{c}0.789 * \\
(0.083)\end{array}$ & $\begin{array}{c}0.599 * \\
(0.078)\end{array}$ & $\begin{array}{l}0.763 * \\
(0.111)\end{array}$ & $\begin{array}{l}0.749 * \\
(0.077)\end{array}$ & $\begin{array}{c}0.681 * \\
(0.070)\end{array}$ & $\begin{array}{c}1.073 * \\
(0.129)\end{array}$ \\
\hline College & $\begin{array}{l}0.757 * \\
(0.128)\end{array}$ & $\begin{array}{l}0.661 * \\
(0.107)\end{array}$ & $\begin{array}{l}0.769 * \\
(0.199)\end{array}$ & $\begin{array}{c}0.773 * \\
(0.161)\end{array}$ & $\begin{array}{c}0.714^{*} \\
(0.120)\end{array}$ & $\begin{array}{c}0.190 \\
(0.257) \\
\end{array}$ \\
\hline \multicolumn{7}{|l|}{ Cost } \\
\hline Constant & $\begin{array}{c}0.830 \\
(0.640)\end{array}$ & $\begin{array}{c}-0.427 \\
(0.534)\end{array}$ & $\begin{array}{c}-0.293 \\
(0.550)\end{array}$ & $\begin{array}{c}0.526 \\
(1.599)\end{array}$ & $\begin{array}{c}0.334 \\
(0.629)\end{array}$ & $\begin{array}{c}0.989 \\
(1.154)\end{array}$ \\
\hline Age & $\begin{array}{c}0.128 * \\
(0.040)\end{array}$ & $\begin{array}{c}0.198 * \\
(0.032)\end{array}$ & $\begin{array}{c}0.243 \\
(0.335)\end{array}$ & $\begin{array}{l}0.182 * \\
(0.097)\end{array}$ & $\begin{array}{l}0.205 * \\
(0.038)\end{array}$ & $\begin{array}{l}0.167 * \\
(0.069)\end{array}$ \\
\hline $\mathrm{Age}^{2}$ & $\begin{array}{l}-0.001 * \\
(0.001)\end{array}$ & $\begin{array}{l}-0.002 * \\
(0.001)\end{array}$ & $\begin{array}{l}-0.003 \\
(0.004)\end{array}$ & $\begin{array}{l}-0.002 * \\
(0.001)\end{array}$ & $\begin{array}{l}-0.002 * \\
(0.001)\end{array}$ & $\begin{array}{l}-0.002 * \\
(0.001)\end{array}$ \\
\hline Male & $\begin{array}{l}0.995 * \\
(0.077)\end{array}$ & $\begin{array}{l}0.964 * \\
(0.071)\end{array}$ & $\begin{array}{l}0.719 * \\
(0.123)\end{array}$ & $\begin{array}{l}1.059 * \\
(0.083)\end{array}$ & $\begin{array}{l}0.890 * \\
(0.079)\end{array}$ & $\begin{array}{l}1.158 * \\
(0.118)\end{array}$ \\
\hline City & $\begin{array}{l}-0.025 \\
(0.070)\end{array}$ & $\begin{array}{c}0.014 \\
(0.069)\end{array}$ & $\begin{array}{c}0.032 \\
(0.107)\end{array}$ & $\begin{array}{l}-0.087 \\
(0.066)\end{array}$ & $\begin{array}{l}-0.060 \\
(0.061)\end{array}$ & $\begin{array}{l}0.235^{*} \\
(0.089)\end{array}$ \\
\hline $\begin{array}{l}\text { Unemployed } \\
\text { last year (days) }\end{array}$ & $\begin{array}{l}0.002 * \\
(0.001)\end{array}$ & $\begin{array}{l}0.004 * \\
(0.001)\end{array}$ & $\begin{array}{l}-0.001 \\
(0.001)\end{array}$ & $\begin{array}{l}0.005 * \\
(0.001)\end{array}$ & $\begin{array}{l}0.005 * \\
(0.001)\end{array}$ & $\begin{array}{l}0.008 * \\
(0.001)\end{array}$ \\
\hline \multicolumn{7}{|l|}{ Variance } \\
\hline$\sigma_{\varepsilon}^{2}$ & $\begin{array}{l}1.640 * \\
(0.142)\end{array}$ & $\begin{array}{l}1.400 * \\
(0.126)\end{array}$ & $\begin{array}{l}3.093 * \\
(0.432)\end{array}$ & $\begin{array}{l}2.919 * \\
(0.172)\end{array}$ & $\begin{array}{l}2.594^{*} \\
(0.155)\end{array}$ & $\begin{array}{l}6.115^{*} \\
(0.392)\end{array}$ \\
\hline$\sigma_{\mathrm{u}}^{2}$ & $\begin{array}{l}0.352 * \\
(0.015)\end{array}$ & $\begin{array}{l}0.395 * \\
(0.017)\end{array}$ & $\begin{array}{l}0.641 * \\
(0.038)\end{array}$ & $\begin{array}{l}0.656 * \\
(0.034)\end{array}$ & $\begin{array}{l}0.531 * \\
(0.027)\end{array}$ & $\begin{array}{l}1.002 * \\
(0.051)\end{array}$ \\
\hline$\sigma_{\varepsilon u}$ & $\begin{array}{l}-0.233 * \\
(0.045)\end{array}$ & $\begin{array}{l}-0.324 * \\
(0.039)\end{array}$ & $\begin{array}{l}-0.502 * \\
(0.095)\end{array}$ & $\begin{array}{l}-0.714^{*} \\
(0.069)\end{array}$ & $\begin{array}{l}-0.611 * \\
(0.059)\end{array}$ & $\begin{array}{l}-1.306^{*} \\
(0.127)\end{array}$ \\
\hline Log-likelihood & -3713.78 & -3774.10 & -3899.41 & -5421.69 & -5274.48 & -6118.63 \\
\hline L-L No Cost ${ }^{17}$ & -3791.11 & -3857.58 & -4022.17 & -5558.68 & -5410.24 & -6210.72 \\
\hline Chi-Squared & 154.66 & 166.96 & 245.52 & 273.98 & 271.52 & 184.18 \\
\hline L-L No Reward & -3771.44 & -3779.79 & -4027.08 & -5522.81 & -5382.85 & -6184.29 \\
\hline Chi-Squared & 115.32 & 11.38 & 255.34 & 202.24 & 216.74 & 131.32 \\
\hline
\end{tabular}

Note: * significant at the $5 \%$ level. Standard errors are reported within parentheses

\footnotetext{
${ }^{16}$ The table presents the estimates for the first year after training for each cohort. The estimates for the consecutive years (i.e., the second and the third years) can be found Tables A1 and A2a-b in Appendix.

${ }^{17}$ L-L No Cost and L-L No Reward represent the log likelihood function value when estimating the model excluding observed heterogeneity in the cost and reward equation (except for a constant). The critical value at the $5 \%$ significance level for a Chi-Squared(5) distribution is 11.07.
} 
Table 6 Model estimate for random coefficient model one year after the training extended variable specification for foreign-born ${ }^{18}$

\begin{tabular}{|c|c|c|c|c|c|c|}
\hline \multirow[b]{2}{*}{ Variables } & \multicolumn{2}{|c|}{ Cohort 1} & \multicolumn{2}{|c|}{ Cohort 2} & \multicolumn{2}{|c|}{ Cohort 3} \\
\hline & Parameter & Standard err. & Parameter & Standard err. & Parameter & Standard err. \\
\hline \multicolumn{3}{|c|}{ Years in Sweden } & \multicolumn{4}{|l|}{ Earnings } \\
\hline $6-10$ & -0.065 & 0.070 & $-0.114^{*}$ & 0.064 & -0.092 & 0.074 \\
\hline $11-$ & 0.031 & 0.066 & -0.020 & 0.058 & -0.048 & 0.064 \\
\hline \multicolumn{7}{|l|}{ Origin } \\
\hline Northern E. & -0.029 & 0.065 & $-0.168 *$ & 0.059 & -0.120 & 0.082 \\
\hline Eastern E. & -0.099 & 0.069 & $-0.267 *$ & 0.056 & $-0.224^{*}$ & 0.078 \\
\hline Southern E. & $-0.287 *$ & 0.057 & $-0.306^{*}$ & 0.057 & -0.061 & 0.079 \\
\hline Middle East & $-0.130 *$ & 0.065 & $-0.402 *$ & 0.057 & $-0.417 *$ & 0.065 \\
\hline Other & $-0.260 *$ & 0.075 & $-0.209 *$ & 0.058 & $-0.284 *$ & 0.070 \\
\hline \multicolumn{3}{|c|}{ Years in Sweden } & \multicolumn{3}{|l|}{ Reward } & \\
\hline $6-10$ & $0.681 *$ & 0.117 & $0.578^{*}$ & 0.108 & $0.398 *$ & 0.148 \\
\hline $11-$ & $0.504 *$ & 0.104 & $0.631 *$ & 0.095 & 0.135 & 0.137 \\
\hline \multicolumn{7}{|l|}{ Origin } \\
\hline Northern E. & $0.569 *$ & 0.144 & $0.510 *$ & 0.144 & $0.674 *$ & 0.224 \\
\hline Eastern E. & $0.714^{*}$ & 0.133 & $0.770 *$ & 0.113 & $0.915^{*}$ & 0.173 \\
\hline Southern E. & $0.724 *$ & 0.117 & $0.855^{*}$ & 0.125 & $0.500^{*}$ & 0.208 \\
\hline Middle East & $0.489 *$ & 0.127 & $0.774 *$ & 0.119 & $0.833^{*}$ & 0.149 \\
\hline Other & $0.730 *$ & 0.125 & $0.719^{*}$ & 0.108 & $0.857 *$ & 0.152 \\
\hline
\end{tabular}

Note: $0-5$ years represents the reference category for years in Sweden, and Nordic countries represent the reference group for the origin.

In the cost equation the estimated age coefficients generally imply that costs increase with age, but at a decreasing pace. The cost for a male relative to a female is always positive. With only one exception, the coefficient indicating the number of days in unemployment the year before training is positive and large in relation to its standard error. This is opposite of what we would expect, since it is more reasonable to think that a longer unemployment period would increase the probability of going into a program. What we see here might be an indication of "cream-skimming" in the sense that those most likely to receive an employment after the training were selected into the program. In the descriptive statistics we see that over all cohorts the number of days of unemployment the year before training is shorter for the trainees than it is for the nontrainees. The sign of the coefficient for the number of days of unemployment mirrors

\footnotetext{
${ }^{18}$ When estimating the models with the foreign-born we extend the variable specification in the earnings and the reward equation, because we believe that time in the country and place of origin are important determinants in the selection effect as well as in the outcome equation. The estimates belong to the results in Table 5 and are separated only to simplify the presentation.
} 
this fact and supports the cream-skimming hypothesis to the extent that the probability of employment is decreasing in the duration of unemployment..

The two variables representing the exclusion restrictions (city region and days of unemployment last year) have different effects on the selection process. Living in a city region representing the distance to the training center has no effect during good economic climates, while it has some effect during a recession for the foreign-born people in the third cohort.

The third cohort is somewhat different in structure compared to the other cohorts since Sweden was faced with a wave of immigrants that to some extent became a target population for the labor market programs, since the immigrants' situation on the labor market was difficult. Groups of people among the foreign-born participated in programs that were of preparatory nature, such as language courses, and most often the groups were clustered in city regions. That might be one reason for the positive and significant effect of the city region indicator received for the third cohort. The second identifying variable, the number of days of unemployment the year before treatment, is significant over the cohorts and groups. ${ }^{19}$ The Swedish-born in the third cohort are an exception.

At the bottom of Table 5 we present the log-likelihood values for specifications where observed heterogeneity with respect to cost and reward are disregarded and set to zero (except for a constant), one at a time. We observe that a likelihood ratio test would reject the null hypothesis (on a 5\% significance level) that the observed cost or observed reward heterogeneity had no influence on the model. That is a justification for the statement that heterogeneity in rewards is important to control for. For the foreign-born group it is even more important, since they are more heterogeneous then the Swedishborn group.

The central interest of this study is on treatment-effects using earnings as the outcome variable; these are reported in Table 7 as well as illustrated in Figure 2. There are several findings to comment on. We have positive rewards for a majority (or nearly a majority) of the treated between the first two cohorts, as well as in some cases for the third cohort. Comparing results cross cohorts we find that foreign-born in the third

\footnotetext{
${ }^{19}$ Number of days of unemployment the year before training is based on the amount of unemployment compensation (UI or CA) an individual received the year before training. Hence, the variable is an estimate that is based on what an average individual received in compensation per day, which therefore might be exposed to some bias.
} 
cohort as measured shortly after training, clearly stand out. Only a small proportion of the treated have positive treatment effects one and two years after completed training. However, the proportion was slightly over $50 \%$ three years after completed training. ${ }^{20}$ The results thus clearly suggest that a deteriorating labor market worsens the prospects for trainees. This comes as no surprise and has been shown in administrative follow-up studies (See Ds 2000:38, p 195). However, our results indicate that such an effect is limited to foreign-born trainees and to the first two years after training.

Table 7a Treatment on the treated effects for 1984/85-year cohort (standard errors in parentheses)

\begin{tabular}{c|c|c|c|c}
\hline Year & Mean effect/Swedish & $\mathrm{P}\left(\mathrm{Y}_{1}-\mathrm{Y}_{0}>0\right)$ & Mean effect/foreign & $\mathrm{P}\left(\mathrm{Y}_{1}-\mathrm{Y}_{0}>0\right)$ \\
\hline 1986 & -0.027 & 38 & $\begin{array}{c}0.069 \\
(0.052)\end{array}$ & 57 \\
\hline 1987 & $\begin{array}{c}0.049) \\
(0.046)\end{array}$ & 74 & $\begin{array}{l}0.262^{*} \\
(0.048)\end{array}$ & 83 \\
\hline 1988 & $\begin{array}{c}0.005 \\
(0.048)\end{array}$ & 51 & $\begin{array}{c}0.176^{*} \\
(0.047)\end{array}$ & 66 \\
\hline
\end{tabular}

Note: * significant at the $5 \%$ level.

Table $7 \mathbf{b}$ Treatment on the treated effects for 1987/88-year cohort (standard errors in parentheses)

\begin{tabular}{c|c|c|c|c}
\hline Year & Mean effect/Swedish & $\mathrm{P}\left(\mathrm{Y}_{1}-\mathrm{Y}_{0}>0\right)$ & Mean effect/foreign & $\mathrm{P}\left(\mathrm{Y}_{1}-\mathrm{Y}_{0}>0\right)$ \\
\hline 1989 & $\begin{array}{c}0.084^{*} \\
(0.041)\end{array}$ & 68 & $\begin{array}{c}0.062 \\
(0.049)\end{array}$ & 58 \\
\hline 1990 & $\begin{array}{c}0.035 \\
(0.039)\end{array}$ & 56 & $\begin{array}{c}0.194^{*} \\
(0.047)\end{array}$ & 82 \\
\hline 1991 & $\begin{array}{l}0.129^{*} \\
(0.040)\end{array}$ & 80 & $\begin{array}{l}0.323^{*} \\
(0.050)\end{array}$ & 93 \\
\hline
\end{tabular}

Note: * significant at the $5 \%$ level.

Table 7c Treatment on the treated effects for 1990/91-year cohort (standard errors in parentheses)

\begin{tabular}{c|c|c|c|c}
\hline Year & Mean effect/Swedish & $\mathrm{P}\left(\mathrm{Y}_{1}-\mathrm{Y}_{0}>0\right)$ & Mean effect/foreign & $\mathrm{P}\left(\mathrm{Y}_{1}-\mathrm{Y}_{0}>0\right)$ \\
\hline \multirow{2}{*}{1992} & 0.016 & 57 & $\begin{array}{c}-0.485^{*} \\
(0.080)\end{array}$ & 18 \\
\hline \multirow{2}{*}{1993} & $(0.083)$ & 50 & $\begin{array}{c}-0.472^{*} \\
(0.081)\end{array}$ & 6 \\
\hline \multirow{2}{*}{1994} & $\begin{array}{c}-0.003 \\
(0.087)\end{array}$ & 39 & $\begin{array}{c}0.031 \\
(0.078)\end{array}$ & 59 \\
\hline
\end{tabular}

Note: * significant at the $5 \%$ level.

${ }^{20} \mathrm{P}\left(\mathrm{Y}_{1}-\mathrm{Y}_{0}>0\right)$ given in Table 7 , denotes the share of trainees with positive reward. The reward is calculated for each trainee, using equation 18. Those with a positive value as a fraction of the total number of trainees in the sample generate the numbers in the table. 
The structure and composition of the foreign-born group changes dramatically during the beginning of the 90 's. Sweden received a large group of immigrants that did not speak Swedish. The labor market programs offer two kinds of courses. The first is of a preparatory nature and the second is of a vocational nature. The relation between the two changes over time due to an increasing number of foreigners taking language courses or other courses of preparatory nature. In 1991 around $60 \%$ of the foreign-born trainees were in non-vocational courses not designed to increase the probability of employment but rather, to prepare for further training (Regnér, 1997). This obviously has some effect on the reward to training since the control group consists of unemployed individuals not taking part in training and, therefore, available to participate in labor market activities. We believe that is the major cause of the discrepancy between trainees and non-trainees for the foreign-born group in the third cohort in Figure 2.

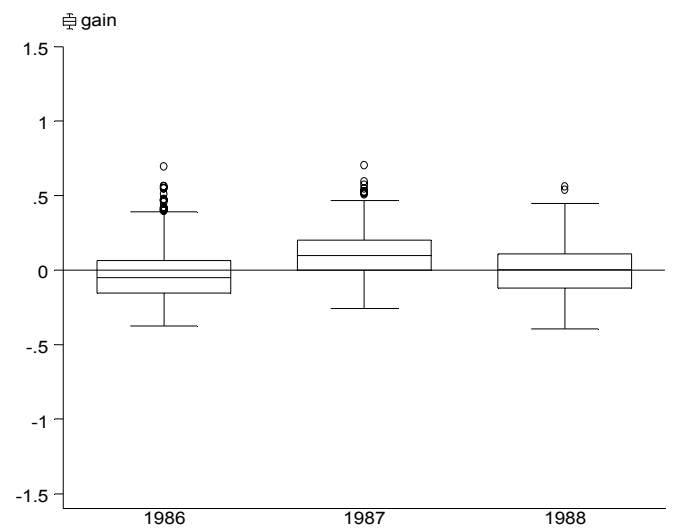

a) Swedish-born trainees

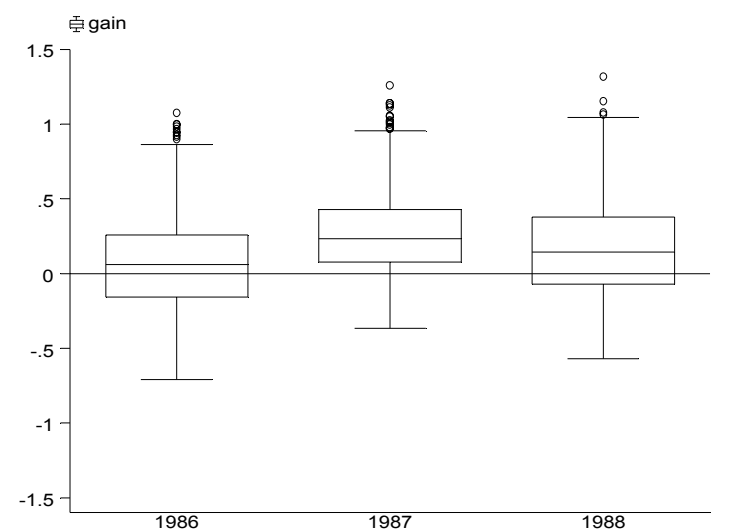

b) Foreign-born trainees

Figure 2a Reward dispersion for 1984/1985-year cohort on log earnings ${ }^{21}$

\footnotetext{
${ }^{21}$ Box-plot explanation: the line in the middle of the box represents the median or $50^{\text {th }}$ percentile of the data. The box extends from the $25^{\text {th }}$ percentile to the $75^{\text {th }}$ percentile, the so-called interquartile range. The lines emerging from the box extend to the upper and lower adjacent values which is defined as plus minus 1.5 times the interquartile range.
} 


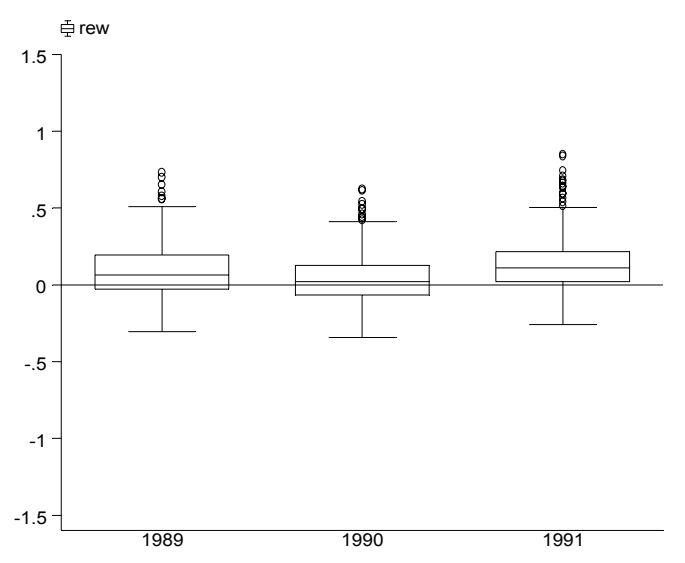

a) Swedish-born trainees

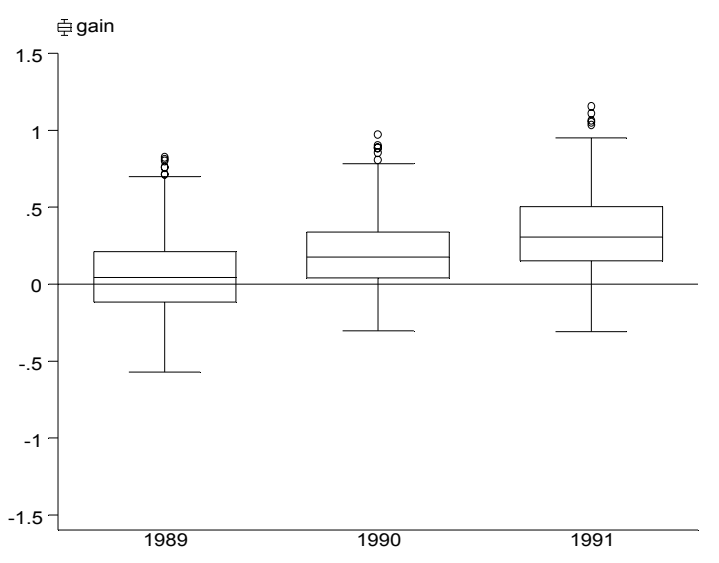

b) Foreign-born trainees

Figure 2b Reward dispersion for 1987/1988-year cohort on log earnings

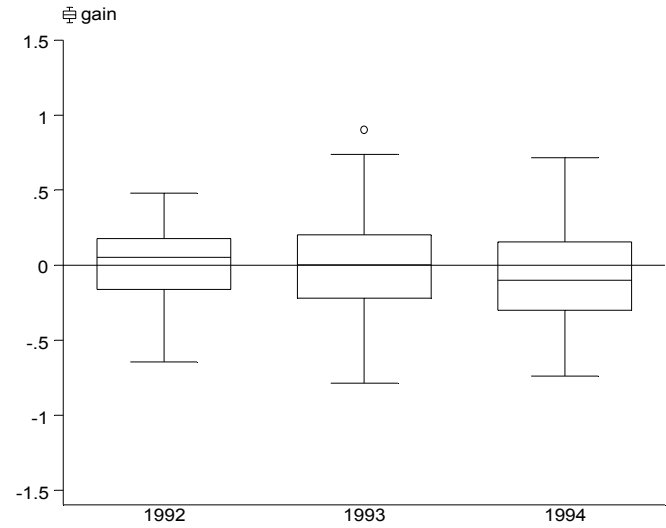

a) Swedish-born trainees

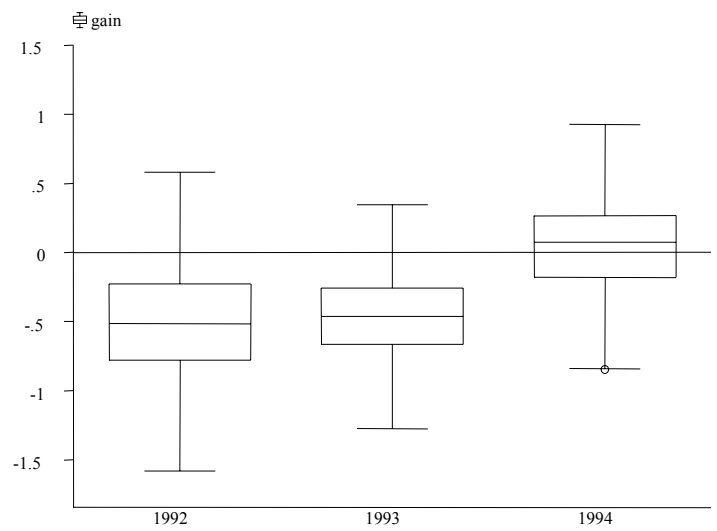

b) Foreign-born trainees

Figure 2c Reward dispersion for 1990/1991-year cohort on log earnings

As was conjectured from inspecting Figure 1, the estimated mean effect of training for foreign-born belonging to the first two cohorts is positive and in most cases larger than for natives.

Table 8 presents a way to identify the characteristics of the individuals that are located on the lower and upper part of the reward distribution. For each cohort we determine the full distribution of the rewards generated by equation (18). Having done that, we truncated the distribution at the lower $25^{\text {th }}$ percentile and the upper $75^{\text {th }}$ percentile. For each of these two parts of the distribution we the compare the proportions of individuals with different kinds of characteristics. 
Table 8a Characteristics for the lower $25^{\text {th }}$ percentile and upper $75^{\text {th }}$ percentile of the reward distribution, for the 1984/1985-year cohort over the observation period for Swedish-born participants

\begin{tabular}{lcc|cc|cc}
\hline & \multicolumn{2}{c|}{1986} & \multicolumn{2}{c}{1987} & \multicolumn{2}{c}{1988} \\
\cline { 2 - 7 } Variables & 25th & 75th & 25th & 75th & 25th & 75th \\
\hline Age groups (\%) & & & & & & 32.3 \\
$\quad$ 20-25 & 50.8 & 13.0 & 56.0 & 15.3 & 28.7 & 37.9 \\
$26-45$ & 49.2 & 43.1 & 43.2 & 52.4 & 71.3 & 29.8 \\
$\quad$ 46-55 & 0.0 & 43.9 & 0.8 & 32.3 & 0.0 & \\
Education (\%) & & & & & \\
$\quad$ Primary & 79.2 & 22.0 & 64.8 & 16.1 & 86.9 & 49.2 \\
$\quad$ Secondary & 16.7 & 67.5 & 33.6 & 62.1 & 13.1 & 44.4 \\
$\quad$ Post Secondary & 4.2 & 10.6 & 1.6 & 21.8 & 0.0 & 52.4 \\
Gender (male) (\%) & 43.3 & 42.3 & 17.6 & 69.3 & 36.1 & 34.6 \\
Married (\%) & 15.0 & 44.7 & 21.6 & 34.7 & 28.7 & 14.5 \\
Number of children age 0-6 (\%) & 20.8 & 8.9 & 26.4 & 8.1 & 25.4 & 12.1 \\
Number of children age 7-12(\%) & 11.7 & 11.4 & 13.6 & 12.1 & 18.9 & 65.2 \\
Unemployed last year (\%) & 10.1 & 66.1 & 9.3 & 71.3 & 9.2 & 108.1 \\
Number of days in training (days) & 99.4 & 101.2 & 103.9 & 102.4 & 108.5 \\
\hline
\end{tabular}

Table 8b Characteristics for the lower $25^{\text {th }}$ percentile and upper $75^{\text {th }}$ percentile of the reward distribution, for the 1984/1985-year cohort over the observation period for foreign-born participants

\begin{tabular}{|c|c|c|c|c|c|c|}
\hline \multirow[b]{2}{*}{ Variables } & \multicolumn{2}{|c|}{1986} & \multicolumn{2}{|c|}{1987} & \multicolumn{2}{|c|}{1988} \\
\hline & 25 th & 75 th & $25^{\text {th }}$ & 75 th & 25 th & 75 th \\
\hline \multicolumn{7}{|l|}{ Age groups (\%) } \\
\hline $20-25$ & 47.8 & 7.8 & 48.8 & 7.8 & 22.9 & 19.1 \\
\hline $26-45$ & 45.7 & 77.0 & 41.1 & 79.6 & 68.6 & 65.0 \\
\hline $46-55$ & 6.5 & 15.2 & 10.2 & 12.7 & 8.6 & 15.6 \\
\hline \multicolumn{7}{|l|}{ Education (\%) } \\
\hline Primary & 88.2 & 15.2 & 79.2 & 22.9 & 90.6 & 11.0 \\
\hline Secondary & 11.4 & 76.6 & 14.2 & 73.1 & 2.4 & 84.9 \\
\hline Post Secondary & 0.4 & 8.2 & 6.5 & 4.1 & 6.9 & 4.1 \\
\hline Gender (male) & 28.2 & 63.9 & 31.3 & 62.4 & 46.9 & 53.3 \\
\hline Married (\%) & 46.1 & 58.6 & 45.5 & 60.0 & 45.7 & 56.5 \\
\hline Unemployed last year (\%) & 3.9 & 60.7 & 2.88 & 63.1 & 1.7 & 59.5 \\
\hline Number of days in training & 124.3 & 142.9 & 119.1 & 146.5 & 132.5 & 149.7 \\
\hline $0-5$ years in the country $(\%)$ & 45.3 & 11.4 & 48.7 & 8.9 & 56.3 & 8.5 \\
\hline $6-10$ years in the country $(\%)$ & 6.9 & 33.6 & 7.3 & 34.3 & 8.5 & 30.8 \\
\hline More then 10 years $(\%)$ & 47.7 & 54.9 & 43.9 & 56.7 & 35.1 & 60.5 \\
\hline Nordic country $(\%)$ & 54.7 & 20.9 & 55.7 & 18.7 & 54.3 & 17.8 \\
\hline Northern Europe (\%) & 6.9 & 9.0 & 6.9 & 8.5 & 8.5 & 10.1 \\
\hline Eastern Europe $(\%)$ & 2.9 & 19.7 & 1.6 & 21.2 & 0.0 & 27.6 \\
\hline Southern Europe $(\%)$ & 4.1 & 22.1 & 2.4 & 26.1 & 4.9 & 19.9 \\
\hline Middle East (\%) & 21.2 & 8.2 & 21.9 & 7.3 & 13.4 & 12.6 \\
\hline Rest of the world (\%) & 10.2 & 20.1 & 11.4 & 17.9 & 18.7 & 11.7 \\
\hline
\end{tabular}


Table 8c Characteristics for the lower $25^{\text {th }}$ percentile and upper $75^{\text {th }}$ percentile of the reward distribution, for the 1987/1988-year cohort over the observation period for Swedish-born participants

\begin{tabular}{l|cc|cc|cc}
\hline \multirow{2}{*}{ Variables } & \multicolumn{2}{c|}{1989} & \multicolumn{2}{c|}{1990} & \multicolumn{2}{c}{1991} \\
\cline { 2 - 7 } & 25th & 75th & 25th & 75 th & 25 th & 75th \\
\hline Age groups (\%) & & & & & & \\
$\quad 20-25$ & 13.3 & 79.2 & 24.0 & 70.9 & 38.2 & 48.1 \\
$26-45$ & 71.8 & 17.7 & 66.7 & 21.3 & 53.9 & 37.9 \\
46-55 & 14.8 & 3.1 & 9.3 & 7.6 & 7.8 & 13.9 \\
\hline Education (\%) & & & & & & \\
$\quad$ Primary & 19.5 & 34.6 & 22.5 & 26.7 & 44.5 & 12.4 \\
$\quad$ Secondary & 64.1 & 50.7 & 68.9 & 49.6 & 39.8 & 75.9 \\
$\quad$ Post Secondary & 16.4 & 14.6 & 8.5 & 23.6 & 15.6 & 11.6 \\
\hline Gender (male) (\%) & 32.0 & 56.9 & 53.4 & 39.7 & 20.3 & 70.5 \\
Married (\%) & 27.3 & 10.7 & 20.2 & 15.3 & 20.3 & 21.7 \\
Number of children age 0-6 (\%) & 28.1 & 17.6 & 24.8 & 18.3 & 21.8 & 14.7 \\
Number of children age 7-12(\%) & 17.2 & 4.6 & 10.1 & 8.4 & 14.8 & 13.9 \\
Unemployed last year (\%) & 2.7 & 39.8 & 1.5 & 41.3 & 1.0 & 42.5 \\
Number of days in training (days) & 146.5 & 114.2 & 131.7 & 136.7 & 121.9 & 129.7 \\
\hline
\end{tabular}

Table 8d Characteristics for the lower $25^{\text {th }}$ percentile and upper $75^{\text {th }}$ percentile of the reward distribution, for the 1987/1988-year cohort over the observation period for foreign-born participants

\begin{tabular}{l|cc|cc|cc}
\hline \multirow{2}{*}{ Variables } & \multicolumn{2}{c|}{1989} & \multicolumn{2}{c|}{1990} & \multicolumn{2}{c}{1991} \\
\cline { 2 - 7 } Age groups (\%) & 25 th & 75 th & 25 th & 75 th & 25 th & $75^{\text {th }}$ \\
$\quad 20-25$ & 27.5 & 13.3 & 32.5 & 12.4 & 30.7 & 15.4 \\
$26-45$ & 65.4 & 65.8 & 57.9 & 70.9 & 58.9 & 67.5 \\
46-55 & 7.1 & 20.8 & 9.6 & 16.5 & 10.4 & 17.1 \\
\hline Education (\%) & & & & & & \\
$\quad$ Primary & 72.5 & 15.8 & 61.6 & 13.2 & 71.3 & 5.0 \\
$\quad$ Secondary & 23.3 & 72.9 & 32.1 & 75.1 & 18.6 & 85.8 \\
$\quad$ Post Secondary & 4.2 & 11.3 & 6.3 & 11.6 & 9.9 & 9.2 \\
\hline Gender (male) (\%) & 38.3 & 67.9 & 40.0 & 70.1 & 40.2 & 70.4 \\
Married (\%) & 40.0 & 47.5 & 35.8 & 49.7 & 34.0 & 48.7 \\
Number of children age 0-6 (\%) & 32.5 & 20.8 & 33.7 & 25.7 & 28.2 & 24.1 \\
Number of children age 7-12 (\%) & 18.3 & 20.4 & 16.6 & 22.4 & 19.5 & 23.7 \\
Percentage unemployed last year (\%) & 2.2 & 41.0 & 2.2 & 41.2 & 2.9 & 37.9 \\
Number of days in training (\%) & 115.6 & 158.2 & 122.6 & 153.2 & 115.8 & 175.8 \\
\hline 0-5 years in the country (\%) & 47.9 & 11.6 & 47.1 & 12.0 & 24.8 & 30.0 \\
6-10years in the country (\%) & 14.2 & 27.1 & 12.9 & 29.8 & 20.7 & 23.7 \\
More then 10 years (\%) & 37.9 & 61.2 & 40.0 & 58.1 & 54.3 & 46.2 \\
\hline Nordic country (\%) & 55.8 & 11.6 & 57.9 & 11.6 & 65.5 & 10.0 \\
Northern Europe (\%) & 9.2 & 2.9 & 2.5 & 10.7 & 4.1 & 6.7 \\
Eastern Europe (\%) & 6.3 & 20.8 & 6.5 & 19.5 & 10.4 & 14.5 \\
Southern Europe (\%) & 1.3 & 24.2 & 2.9 & 17.8 & 2.9 & 17.1 \\
Middle East (\%) (\%) & 13.7 & 20.8 & 9.5 & 25.3 & 6.2 & 31.6 \\
Rest of the world (\%) & 13.7 & 19.6 & 20.8 & 14.9 & 10.7 & 20.0 \\
\hline
\end{tabular}


Table 8e Characteristics for the lower $25^{\text {th }}$ percentile and upper $75^{\text {th }}$ percentile of the reward distribution, for the 1990/1991-year cohort over the observation period for foreign-born participants

\begin{tabular}{l|cc|cc|cc}
\hline & \multicolumn{2}{c}{1992} & \multicolumn{2}{c|}{1993} & \multicolumn{2}{c}{1994} \\
\cline { 2 - 7 } & 25th & 75 th & 25th & 75 th & 25 th & 75th \\
\hline Age groups (\%) & & & & & & \\
$20-25$ & 57.2 & 18.5 & 65.5 & 9.2 & 52.9 & 20.6 \\
$26-45$ & 19.6 & 70.5 & 21.0 & 74.7 & 23.5 & 70.2 \\
46-55 & 23.1 & 10.9 & 13.4 & 15.9 & 23.5 & 9.1 \\
\hline Education (\%) & & & & & & \\
$\quad$ Primary & 82.1 & 0 & 57.1 & 2.5 & 70.5 & 0.8 \\
$\quad$ Secondary & 13.6 & 75.6 & 9.2 & 97.4 & 0.0 & 99.1 \\
$\quad$ Post Secondary & 4.3 & 24.3 & 33.6 & 0.0 & 29.4 & 0.0 \\
\hline Gender (male) (\%) & 15.4 & 85.7 & 20.1 & 64.7 & 19.3 & 73.5 \\
Married (\%) & 30.7 & 33.6 & 20.1 & 35.3 & 27.7 & 31.4 \\
Number of children age 0-6 (\%) & 18.8 & 21.8 & 17.6 & 19.3 & 18.4 & 18.1 \\
Number of children age 7-12 (\%) & 9.4 & 14.2 & 6.7 & 19.3 & 6.7 & 15.7 \\
Percentage unemployed last year (\%) & 9.0 & 11.6 & 3.0 & 18.2 & 2.3 & 18.7 \\
Number of days in training (days) & 107.7 & 132.1 & 115.7 & 124.3 & 120.1 & 126.6 \\
\hline
\end{tabular}

Table 8f Characteristics for the lower $25^{\text {th }}$ percentile and upper $75^{\text {th }}$ percentile of the reward distribution, for the 1984/1985-year cohort over the observation period for foreign-born participants

\begin{tabular}{l|cc|cc|cc}
\hline & \multicolumn{2}{c|}{1992} & \multicolumn{2}{c|}{1993} & \multicolumn{2}{c}{1994} \\
\cline { 2 - 7 } & 25 th & 75 th & 25 th & 75 th & 25 th & 75 th \\
\hline Age groups (\%) & & & & & & \\
$20-25$ & 40.2 & 13.6 & 35.5 & 5.7 & 27.2 & 7.3 \\
$26-45$ & 46.5 & 69.5 & 53.7 & 78.5 & 55.7 & 84.8 \\
46-55 & 13.3 & 16.8 & 10.7 & 15.7 & 16.9 & 7.7 \\
\hline Education (\%) & & & & & & \\
$\quad$ Primary & 80.1 & 6.9 & 61.9 & 27.6 & 51.6 & 34.8 \\
Secondary & 2.9 & 92.5 & 4.5 & 72.3 & 13.6 & 65.2 \\
$\quad$ Post Secondary & 17.0 & 0.4 & 33.4 & 0.0 & 34.7 & 0.0 \\
\hline Gender (male) (\%) & 43.9 & 57.2 & 51.6 & 46.2 & 37.1 & 57.3 \\
Married (\%) & 36.5 & 61.3 & 42.1 & 61.9 & 42.1 & 64.3 \\
Number of children age 0-6 (\%) & 20.7 & 36.2 & 26.4 & 37.6 & 22.7 & 37.7 \\
Number of children age 7-12(\%) & 17.8 & 25.1 & 15.2 & 28.9 & 19.4 & 30.3 \\
Unemployed last year (\%) & 4.0 & 16.3 & 2.0 & 20.4 & 3.3 & 17.2 \\
Number of days in training (days) & 128.8 & 157.2 & 157.1 & 140.3 & 136.7 & 159.7 \\
\hline 0-5 years in the country (\%) & 31.5 & 50.6 & 57.4 & 29.3 & 32.2 & 53.2 \\
6-10years in the country (\%) & 7.8 & 23.4 & 7.0 & 31.4 & 10.3 & 22.9 \\
More then 10 years (\%) & 60.5 & 25.9 & 35.5 & 39.2 & 57.4 & 23.7 \\
\hline Nordic country (\%) & 59.7 & 5.3 & 47.9 & 4.9 & 69.4 & 0.0 \\
Northern Europe (\%) & 4.5 & 6.2 & 3.7 & 4.9 & 2.5 & 0.8 \\
Eastern Europe (\%) & 2.1 & 20.2 & 4.1 & 23.9 & 3.7 & 31.1 \\
Southern Europe (\%) & 12.0 & 7.8 & 2.5 & 10.3 & 4.1 & 1.6 \\
Middle East (\%) (\%) & 13.2 & 33.3 & 26.4 & 30.1 & 13.2 & 25.8 \\
Rest of the world (\%) & 8.3 & 27.2 & 15.3 & 25.6 & 7.0 & 40.5 \\
\hline
\end{tabular}


In order to summarize the information we have also constructed Table 9. The idea for this table is to count the number of the six samples defined by cohort and country of origin where there are consistent indications of a low respectively high position in the reward distribution. There is also one column for indications of the position in the reward distribution being non-conclusive. When discussing the results we will start from the information in Table 9 and when motivated, also refer to those in Table 8.

Table 9 Summary of results reported in Table 8

\begin{tabular}{|c|c|c|c|}
\hline Subgroup & $\begin{array}{l}\text { Consistent indications of } \\
\text { a low position in the } \\
\text { reward distribution }\end{array}$ & Not conclusive & $\begin{array}{l}\text { Consistent indication of } \\
\text { a high position in the } \\
\text { reward distribution }\end{array}$ \\
\hline & \multicolumn{3}{|c|}{ Number of Indications } \\
\hline \multicolumn{4}{|l|}{ Age of the person } \\
\hline $20-25$ & 5 & 0 & 1 \\
\hline $26-45$ & 1 & 2 & 3 \\
\hline $46-55$ & 0 & 5 & 1 \\
\hline \multicolumn{4}{|l|}{ Education of the person } \\
\hline Primary & 5 & 1 & 0 \\
\hline Secondary & 0 & 1 & 5 \\
\hline Post secondary & 2 & 3 & 1 \\
\hline Male & 0 & 0 & 6 \\
\hline Married & 0 & 2 & 4 \\
\hline \multicolumn{4}{|c|}{ Variables specific to native-born } \\
\hline $\begin{array}{l}\text { Number of children } \\
\text { aged } 0-6\end{array}$ & 1 & 2 & 0 \\
\hline $\begin{array}{l}\text { Number of children } \\
\text { Aged } 7-12\end{array}$ & 0 & 3 & 0 \\
\hline \multicolumn{4}{|c|}{ Variables specific to foreign-born } \\
\hline $0-5$ years in the country & 2 & 1 & 0 \\
\hline $\begin{array}{l}6-10 \text { years in the } \\
\text { country }\end{array}$ & 0 & 1 & 2 \\
\hline $\begin{array}{l}\text { More than } 10 \text { years in } \\
\text { the country }\end{array}$ & 1 & 0 & 2 \\
\hline \multicolumn{4}{|l|}{ Originating from } \\
\hline A Nordic country & 3 & 0 & 0 \\
\hline Northern Europe & 0 & 3 & 0 \\
\hline Eastern Europe & 0 & 0 & 3 \\
\hline Southern Europe & 0 & 1 & 2 \\
\hline Middle East & 0 & 1 & 2 \\
\hline Rest of the world & 0 & 2 & 1 \\
\hline
\end{tabular}

Note: To be classified as having a consistently high (low) position it is required that the percentage in the $75^{\text {th }}$ percentile differs from the one in the $25^{\text {th }}$ percentile by on average 10 percentage units per year and that a difference of at least 10 percentage units is observed for no less than two years.

Starting with age, there are clear signs of the youngest persons being located in the low position of the reward distribution. The only exception to this is found among the 
second cohort of Swedish-born; persons who terminated training when the labor market prospects became more favorable. There is much less structure as regards the location of the other two age groups. This finding can be understood from the background of relatively few trainees being found in the oldest age group.

The conclusion that rewards for young trainees are generally low can also be backed by results from several Swedish studies referred to in the introduction. Ackum (1991) for example, who studied young adults that received training at approximately the same time as our first cohort, drew a very similar conclusion. In addition, results from two studies on persons who received training at approximately the same time as our third cohort are comparable. The studies are Regnér (1997) and Larsson (2000), the latter focusing on young adults. It is interesting to note that Friedlander et al (1997), when summarizing a number of evaluations of labor market training programs in the United States, drew similar conclusions.

Turning to education, the pattern shows that a primary education also leads to a low position in the reward distribution, while the opposite is the case for secondary education. There is not much of a pattern across the samples when it comes to the position of post-secondary education in the reward distribution. These findings lead to the unanswered question: What can explain why the pay-off from labor market training is higher for those with secondary education, while low for those with only primary education?

According to the findings summarized in Table 9, there is a general pattern of males having a higher position in the reward distribution than females. There is also a pattern, although not equally striking, that married trainees have a higher position in the reward distribution than other trainees. The result mentioned first can be regarded as a controversial finding as it is in conflict with what Regnér (1997) reports for approximately our third cohort.

Finally we comment on variables specific for foreign-born. First, it seems as there is more of a pattern between country of origin and position in the reward distribution, than between years since immigration and position in the reward distribution. People originating from other Nordic countries are generally found in the lower position of the reward distribution, while people from other parts of the world are under-represented at 
the bottom of the reward distribution. The results for people originating from Eastern Europe are consistently found in the top of the reward distribution for all three cohorts.

Table 10 presents another way to examine how rewards vary with characteristics one year after completed training. For natives and foreign-born people of a given gender, we present means and medians the year after completed training, disaggregated by education and age, respectively. Looking at the information in the different cells, the most striking information is that large negative values for foreign-born in the 1990/91 cohort appear in most cells. One can also notice that among natives in the last two cohorts, the values for males are generally higher than for females.

Table 10a Heterogeneity to reward, treatment on the treated for 1984/85-year cohort (standard error in parentheses)

\begin{tabular}{|c|c|c|c|c|c|c|c|}
\hline \multicolumn{2}{|l|}{1986} & \multicolumn{2}{|c|}{ Primary School } & \multicolumn{2}{|c|}{ Secondary School } & \multicolumn{2}{|c|}{ Post Secondary School } \\
\hline & Gender & Mean & Median & Mean & Median & Mean & Median \\
\hline \multirow[t]{2}{*}{ Swedish } & Male & $\begin{array}{c}-0.154 \\
(0.157)\end{array}$ & -0.204 & $\begin{array}{c}0.029 \\
(0.092)\end{array}$ & -0.003 & $\begin{array}{c}-0.014 \\
(0.188)\end{array}$ & -0.029 \\
\hline & Female & $\begin{array}{l}-0.124 \\
(0.115)\end{array}$ & -0.162 & $\begin{array}{c}0.036 \\
(0.088)\end{array}$ & 0.013 & $\begin{array}{c}0.028 \\
(0.201)\end{array}$ & -0.008 \\
\hline \multirow[t]{4}{*}{ Foreign } & Male & $\begin{array}{c}-0.022 \\
(0.113)\end{array}$ & -0.021 & $\begin{array}{l}0.313^{*} \\
(0.101)\end{array}$ & 0.261 & $\begin{array}{c}0.335 \\
(0.314)\end{array}$ & 0.241 \\
\hline & Female & $\begin{array}{l}-0.167 \\
(0.102)\end{array}$ & -0.183 & $\begin{array}{c}0.153 \\
(0.112)\end{array}$ & 0.144 & $\begin{array}{c}0.194 \\
(0.290)\end{array}$ & 0.147 \\
\hline & & \multicolumn{2}{|c|}{ Age (20-25) } & \multicolumn{2}{|c|}{ Age (26-45) } & \multicolumn{2}{|c|}{ Age (46-55) } \\
\hline & Gender & Mean & Median & Mean & Median & Mean & Median \\
\hline \multirow[t]{2}{*}{ Swedish } & & $\begin{array}{c}-0.092 \\
(0.124)\end{array}$ & -0.114 & $\begin{array}{c}-0.051 \\
(0.098)\end{array}$ & -0.044 & $\begin{array}{c}0.390 \\
(0.241)\end{array}$ & 0.393 \\
\hline & Female & $\begin{array}{l}-0.118 \\
(0.117)\end{array}$ & -0.115 & $\begin{array}{l}-0.052 \\
(0.090)\end{array}$ & -0.023 & $\begin{array}{c}0.329 \\
(0.192)\end{array}$ & 0.351 \\
\hline \multirow[t]{2}{*}{ Foreign } & & $\begin{array}{l}-0.049 \\
(0.157)\end{array}$ & -0.029 & $\begin{array}{l}0.212^{*} \\
(0.089)\end{array}$ & 0.191 & $\begin{array}{c}0.277 \\
(0.226)\end{array}$ & 0.245 \\
\hline & Female & $\begin{array}{l}-0.207 \\
(0.146)\end{array}$ & -0.231 & $\begin{array}{c}0.043 \\
(0.092)\end{array}$ & 0.034 & $\begin{array}{c}0.049 \\
(0.220)\end{array}$ & 0.060 \\
\hline
\end{tabular}

Note: * significant at the $5 \%$ level. 
Table 10b Heterogeneity to reward, treatment on the treated for 1987/88-year cohort (standard error in parentheses)

\begin{tabular}{|c|c|c|c|c|c|c|c|}
\hline \multicolumn{2}{|l|}{1989} & \multicolumn{2}{|c|}{ Primary School } & \multicolumn{2}{|c|}{ Secondary School } & \multicolumn{2}{|c|}{ Post Secondary School } \\
\hline & Gender & Mean & Median & Mean & Median & Mean & Median \\
\hline \multirow[t]{2}{*}{ Swedish } & Male & $\begin{array}{c}0.145 \\
(0.128)\end{array}$ & 0.136 & $\begin{array}{c}0.111 \\
(0.075)\end{array}$ & 0.085 & $\begin{array}{c}0.152 \\
(0.188)\end{array}$ & 0.118 \\
\hline & Female & $\begin{array}{c}0.089 \\
(0.105)\end{array}$ & 0.056 & $\begin{array}{c}0.028 \\
(0.076)\end{array}$ & -0.006 & $\begin{array}{c}0.057 \\
(0.107)\end{array}$ & 0.054 \\
\hline \multirow[t]{4}{*}{ Foreign } & Male & $\begin{array}{l}-0.035 \\
(0.116)\end{array}$ & -0.051 & $\begin{array}{c}0.202^{*} \\
(0.084)\end{array}$ & 0.166 & $\begin{array}{c}0.217 \\
(0.232)\end{array}$ & 0.183 \\
\hline & Female & $\begin{array}{c}-0.108 \\
(0.116)\end{array}$ & -0.127 & $\begin{array}{c}0.081 \\
(0.103)\end{array}$ & 0.059 & $\begin{array}{c}0.073 \\
(0.198)\end{array}$ & 0.049 \\
\hline & & \multicolumn{2}{|c|}{ Age (20-25) } & \multicolumn{2}{|c|}{ Age (26-45) } & \multicolumn{2}{|c|}{ Age (45-55) } \\
\hline & Gender & Mean & Median & Mean & Median & Mean & Median \\
\hline \multirow[t]{2}{*}{ Swedish } & & $\begin{array}{c}0.233^{*} \\
(0.098)\end{array}$ & 0.232 & $\begin{array}{c}0.046 \\
(0.089)\end{array}$ & 0.057 & $\begin{array}{c}0.065 \\
(0.182)\end{array}$ & 0.091 \\
\hline & Female & $\begin{array}{l}0.161 * \\
(0.089)\end{array}$ & 0.148 & $\begin{array}{l}-0.024 \\
(0.076)\end{array}$ & -0.008 & $\begin{array}{c}0.027 \\
(0.142)\end{array}$ & 0.030 \\
\hline \multirow[t]{2}{*}{ Foreign } & & $\begin{array}{c}0.031 \\
(0.141)\end{array}$ & 0.013 & $\begin{array}{c}0.118 \\
(0.082)\end{array}$ & 0.115 & $\begin{array}{c}0.273 \\
(0.183)\end{array}$ & 0.228 \\
\hline & Female & $\begin{array}{c}-0.030 \\
(0.163)\end{array}$ & -0.037 & $\begin{array}{c}-0.008 \\
(0.089)\end{array}$ & -0.021 & $\begin{array}{c}0.064 \\
(0.186)\end{array}$ & 0.044 \\
\hline
\end{tabular}

Note: * significant at the $5 \%$ level.

Table 10c Heterogeneity to reward, treatment on the treated for 1990/91-year cohort (standard errror in parentheses)

\begin{tabular}{|c|c|c|c|c|c|c|c|}
\hline \multicolumn{2}{|l|}{1992} & \multicolumn{2}{|c|}{ Primary School } & \multicolumn{2}{|c|}{ Secondary School } & \multicolumn{2}{|c|}{ Post Secondary School } \\
\hline & Gender & Mean & Median & Mean & Median & Mean & Median \\
\hline \multirow[t]{2}{*}{ Swedish } & Male & $\begin{array}{c}-0.036 \\
(0.204)\end{array}$ & -0.001 & $\begin{array}{c}0.268 \\
(0.156)\end{array}$ & 0.266 & $\begin{array}{c}0.299 \\
(0.325)\end{array}$ & 0.327 \\
\hline & Female & $\begin{array}{c}-0.281 \\
(0.185)\end{array}$ & -0.231 & $\begin{array}{c}0.016 \\
(0.186)\end{array}$ & 0.077 & $\begin{array}{c}0.044 \\
(0.259)\end{array}$ & 0.072 \\
\hline \multirow[t]{4}{*}{ Foreign } & Male & $\begin{array}{c}-0.721^{*} \\
(0.162)\end{array}$ & -0.642 & $\begin{array}{c}-0.002 \\
(0.178)\end{array}$ & 0.106 & $\begin{array}{c}-0.861 * \\
(0.461)\end{array}$ & -0.769 \\
\hline & Female & $\begin{array}{c}-0.686 * \\
(0.147)\end{array}$ & -0.612 & $\begin{array}{l}-0.022 \\
(0.204)\end{array}$ & 0.005 & $\begin{array}{c}-0.834 * \\
(0.304)\end{array}$ & -0.675 \\
\hline & & \multicolumn{2}{|c|}{ Age (20-25) } & \multicolumn{2}{|c|}{ Age $(26-45)$} & \multicolumn{2}{|c|}{ Age (46-55) } \\
\hline & Gender & Mean & Median & Mean & Median & Mean & Median \\
\hline \multirow[t]{2}{*}{ Swedish } & Male & $\begin{array}{c}0.023 \\
(0.189)\end{array}$ & 0.091 & $\begin{array}{c}0.279 \\
(0.169)\end{array}$ & 0.341 & $\begin{array}{c}0.142 \\
(0.307)\end{array}$ & 0.094 \\
\hline & Female & $\begin{array}{c}-0.305 \\
(0.230) \\
\end{array}$ & -0.327 & $\begin{array}{c}-0.007 \\
(0.159) \\
\end{array}$ & 0.044 & $\begin{array}{c}-0.143 \\
(0.269) \\
\end{array}$ & -0.175 \\
\hline \multirow[t]{2}{*}{ Foreign } & Male & $\begin{array}{c}-0.711 * \\
(0.283)\end{array}$ & -0.791 & $\begin{array}{c}-0.398^{*} \\
(0.138)\end{array}$ & -0.520 & $\begin{array}{c}-0.359 \\
(0.331)\end{array}$ & -0.370 \\
\hline & Female & $\begin{array}{c}-0.787^{*} \\
(0.255)\end{array}$ & -0.802 & $\begin{array}{c}-0.466^{*} \\
(0.136)\end{array}$ & -0.485 & $\begin{array}{c}-0.407 \\
(0.296)\end{array}$ & -0.301 \\
\hline
\end{tabular}

Note: * significant at the $5 \%$ level.

Earlier, Table $7 \mathrm{a}$ indicated that for the first cohort the overall average effect is insignificant for both Swedish- and foreign-born trainees. Table 10a confirms this for 
different sub-groups. However, foreign-born males with a high-school degree, or in the age interval 26-45 have a positive and significant earnings effect from training. For the Swedish-born trainees no sub-group had any significant training effect on earnings.

The second cohort provides a somewhat different picture for the Swedish-born: young people (20-25) are the main driving force behind the positive effect in Table $7 \mathrm{~b}$. With respect to the foreign-born the impression is about the same as it was for the first cohort, except for the fact that the age effect is insignificant for the second cohort.

For the last cohort, none of the sub-groups among the Swedish-born trainees show estimates significant at conventional levels. For the foreign-born the situation is reversed, and many of the sub-groups show significant earnings effects, yet negative.

In Table 11 the sorting components are presented for the cohorts and groups over the follow-up period. Two interesting components are $\sigma_{1 \varepsilon}$ and $\sigma_{0 \varepsilon}$. Those two covariances give you the size and direction of the selection into the two states. Since $\sigma_{1 \varepsilon}>0$ and $\sigma_{0 \varepsilon}<0$ we have positive selection into both training and non-training, implying that choices are rational in the sense that individuals are selected according to where they will perform best.

In general, the pattern of the components over time is the same for foreign-born and Swedish-born people. The covariance between the two states $\left(\sigma_{10}\right)$ is an exception. For the foreign-born the sign is negative while it is positive for the Swedish-born. This is the case for all three cohorts and is therefore a difference that is independent of the economic climate. The absolute magnitude changes however, but this is the case for both groups. A positive sign indicates that an individual who performs well in one state also will perform well in the other state, and from the discussion above we know that the state is chosen where the reward is highest. For the foreign-born individuals the situation is different with a negative sign. That implies that if they do relatively well in one state they perform relatively poorly in the other state. This implies that the relative importance of the program for foreign-born people is greater than for Swedes.

A test for the importance of the unobserved component of the reward would be a test of $\sigma_{1 \varepsilon}=\sigma_{0 \varepsilon} \Leftrightarrow \sigma_{\varepsilon+\mathrm{u}, \mathrm{u}}=\sigma_{\varepsilon, \mathrm{u}}$. In the table we see that they even have different signs, indicating that controlling for unobserved heterogeneity with respect to the reward is important. Since we know that the individual's ambition to participate in the program is 
a major factor, we know that we do not have access to all relevant variables for the selection process. This makes it even more important to control for such factors.

Table 11a Behavioral components for Swedish-born people (standard errors in parentheses)

\begin{tabular}{|c|c|c|c|c|c|c|c|c|c|}
\hline & \multicolumn{3}{|c|}{ Cohort 1} & \multicolumn{3}{|c|}{ Cohort 2} & \multicolumn{3}{|c|}{ Cohort 3} \\
\hline & 1986 & 1987 & 1988 & 1989 & 1990 & 1991 & 1992 & 1993 & 1994 \\
\hline \multicolumn{10}{|c|}{ Estimated variances and covariance } \\
\hline$\sigma_{0}^{2}$ & $\begin{array}{c}0.352 \\
(0.015)\end{array}$ & $\begin{array}{c}0.403 \\
(0.016)\end{array}$ & $\begin{array}{c}0.373 \\
(0.015)\end{array}$ & $\begin{array}{l}0.395 \\
(0.017)\end{array}$ & $\begin{array}{c}0.332 \\
(0.015)\end{array}$ & $\begin{array}{r}0.409 \\
(0.018)\end{array}$ & $\begin{array}{c}0.641 \\
(0.038)\end{array}$ & $\begin{array}{l}0.835 \\
(0.040)\end{array}$ & $\begin{array}{c}0.724 \\
(0.041)\end{array}$ \\
\hline$\sigma_{\varepsilon}^{2}$ & $\begin{array}{c}1.640 \\
(0.142)\end{array}$ & $\begin{array}{r}1.543 \\
(0.156)\end{array}$ & $\begin{array}{c}1.601 \\
(0.167)\end{array}$ & $\begin{array}{l}1.400 \\
(0.126)\end{array}$ & $\begin{array}{c}1.359 \\
(0.126)\end{array}$ & $\begin{array}{c}1.381 \\
(0.124)\end{array}$ & $\begin{array}{c}3.093 \\
(0.432)\end{array}$ & $\begin{array}{c}3.336 \\
(0.348)\end{array}$ & $\begin{array}{c}3.249 \\
(0.347)\end{array}$ \\
\hline$\sigma_{0 \varepsilon}$ & $\begin{array}{r}-0.233 \\
(0.025) \\
\end{array}$ & $\begin{array}{r}-0.251 \\
(0.046) \\
\end{array}$ & $\begin{array}{l}-0.223 \\
(0.045) \\
\end{array}$ & $\begin{array}{l}-0.324 \\
(0.039) \\
\end{array}$ & $\begin{array}{l}-0.283 \\
(0.037) \\
\end{array}$ & $\begin{array}{r}-0.328 \\
(0.041) \\
\end{array}$ & $\begin{array}{l}-0.502 \\
(0.095) \\
\end{array}$ & $\begin{array}{r}-0.653 \\
(0.101) \\
\end{array}$ & $\begin{array}{c}-0.548 \\
(0.095) \\
\end{array}$ \\
\hline \multicolumn{10}{|c|}{ Implied variance and covariances } \\
\hline$\sigma_{1}^{2}$ & 1.526 & 1.444 & 1.528 & 1.147 & 1.124 & 1.134 & 2.729 & 2.865 & 2.876 \\
\hline$\sigma_{1 \varepsilon}$ & 1.407 & 1.292 & 1.377 & 1.075 & 1.075 & 1.053 & 2.591 & 2.683 & 2.700 \\
\hline$\sigma_{10}$ & 0.119 & 0.152 & 0.151 & 0.071 & 0.049 & 0.081 & 0.138 & 0.182 & 0.176 \\
\hline
\end{tabular}

Table 11b Behavioral components for foreign-born people (standard errors in parentheses)

\begin{tabular}{|c|c|c|c|c|c|c|c|c|c|}
\hline & \multicolumn{3}{|c|}{ Cohort 1} & \multicolumn{3}{|c|}{ Cohort 2} & \multicolumn{3}{|c|}{ Cohort 3} \\
\hline & 1986 & 1987 & 1988 & 1989 & 1990 & 1991 & 1992 & 1993 & 1994 \\
\hline \multicolumn{10}{|c|}{ Estimated variances and covariance } \\
\hline$\sigma_{0}^{2}$ & $\begin{array}{c}0.656 \\
(0.034)\end{array}$ & $\begin{array}{r}0.609 \\
(0.034)\end{array}$ & $\begin{array}{c}0.531 \\
(0.030)\end{array}$ & $\begin{array}{c}0.531 \\
(0.027)\end{array}$ & $\begin{array}{l}0.594 \\
(0.033)\end{array}$ & $\begin{array}{c}0.759 \\
(0.040)\end{array}$ & $\begin{array}{c}1.002 \\
(0.051)\end{array}$ & $\begin{array}{l}1.073 \\
(0.055)\end{array}$ & $\begin{array}{c}1.378 \\
(0.073)\end{array}$ \\
\hline$\sigma_{\varepsilon}^{2}$ & $\begin{array}{l}2.919 \\
(0.172)\end{array}$ & $\begin{array}{c}2.583 \\
(0.069)\end{array}$ & $\begin{array}{r}2.555 \\
(0.137)\end{array}$ & $\begin{array}{c}2.594 \\
(0.155)\end{array}$ & $\begin{array}{c}2.505 \\
(0.150)\end{array}$ & $\begin{array}{c}2.672 \\
(0.168)\end{array}$ & $\begin{array}{c}6.115 \\
(0.392)\end{array}$ & $\begin{array}{c}6.138 \\
(0.382)\end{array}$ & $\begin{array}{c}5.838 \\
(0.362)\end{array}$ \\
\hline$\sigma_{0 \varepsilon}$ & $\begin{array}{c}-0.714 \\
(0.069) \\
\end{array}$ & $\begin{array}{l}-0.762 \\
(0.063) \\
\end{array}$ & $\begin{array}{c}-0.687 \\
(0.058) \\
\end{array}$ & $\begin{array}{c}-0.611 \\
(0.059) \\
\end{array}$ & $\begin{array}{l}-0.677 \\
(0.061)\end{array}$ & $\begin{array}{r}-0.840 \\
(0.072) \\
\end{array}$ & $\begin{array}{r}-1.306 \\
(0.127) \\
\end{array}$ & $\begin{array}{c}-1.410 \\
(0.131) \\
\end{array}$ & $\begin{array}{l}-1.779 \\
(0.142) \\
\end{array}$ \\
\hline \multicolumn{10}{|c|}{ Implied variance and covariances } \\
\hline$\sigma_{1}^{2}$ & 2.147 & 1.667 & 1.711 & 1.902 & 1.745 & 1.751 & 4.505 & 4.391 & 3.658 \\
\hline$\sigma_{1 \varepsilon}$ & 2.205 & 1.820 & 1.868 & 1.983 & 1.828 & 1.832 & 4.809 & 4.728 & 4.059 \\
\hline$\sigma_{10}$ & -0.058 & -0.153 & -0.156 & -0.080 & -0.082 & -0.080 & -0.303 & -0.337 & -0.400 \\
\hline
\end{tabular}

\section{Summary and conclusions}

In this paper we have evaluated labor market training programs in Sweden using non-experimental methods. People who received training in 1984/85, 1987/88 and 1990/91 as well as a control groups were followed using register data. The main outcome variable was earnings as evaluated one, two and three years after completed 
training. Different samples for natives and foreign-born were investigated. We estimate a switching regression model while allowing for unobserved heterogeneity with respect to the reward on training. This allows us to investigate how the reward is distributed across observed characteristics and between individuals.

A number of interesting findings were found and a number of conclusions can be drawn from the study. First, when analyzing treatment effects for trainees and controls, they were found to greatly differ for all cohorts investigated as well as across natives and foreign-born. The difference is found not only when analyzing earnings one year after completed training, but also two and three years after completed training. The differences all mean that there is positive sorting into training.

Second, overall, the proportion having positive rewards from training as evaluated by earnings was not very different from the proportion having negative rewards. The estimates for average rewards from training were in some cases relatively large, but so were the standard errors for the estimate. These results are in line with what was found in earlier studies of training, studies that took place in Sweden during approximately the same period (Zetterberg, 1997). This means that the results from our study do not support the view, which suggests that from efficiency considerations, too few persons were enrolled in labor market training during this period.

Third, comparing results cross cohorts it was found that rewards stand out for the third foreign-born cohort, as most rewards were negative during the first two years following training. However, this changed during the following year. We interpret these findings as being driven by rapidly deteriorating labor market conditions. Thus it seems as though rapid changes in the labor market can drastically affect rewards, but also that such an influence is concentrated to the foreign-born and vanishes over time.

Fourth, when analyzing how rewards differ by characteristics across samples of the trainee, certain patterns were found. Consistent with several previous studies, we found that being a young adult means a negative or low pay-off from training. We also arrived at the same result for persons possessing only primary education. In conflict with what earlier studies have shown, we found that males have a better pay-off from training than females. Further, the results indicate that among immigrants, the pay-off from labor market training varies by origin. Thus the pay-off for a person from Eastern Europe was found to be better that for someone originating from another Nordic country. 
Without additional knowledge it is difficult to offer a well-founded explanation for the finding that rewards were higher for foreign-born than for natives. One plausible explanation stems from the fact that natives and foreigners to some degree attended different training courses. Curriculum's for the courses differ and this might provide a viable explanation for the difference across the two groups. Another reason could be that training reduces the foreigner's reservation wage more than for natives, making them better prepared to accept job offers. A third explanation is that employers use a newly earned certificate for taking part in labor market training as a screening device when selecting foreign workers, but not when selecting native workers.

The estimates imply that we have positive sorting into both training and non-training for both Swedish-born and foreign-born individuals indicating rational behavior with respect to the participation decision. Nevertheless the sorting structure differs between the Swedish-born and the foreign-born. Swedish-born people have a hierarchical structure while the foreign-born have a comparative advantage sorting structure. This difference is independent of the economic climate.

Although we believe our study has produced new insights into the effects of Swedish labor market training, there are also limitations worth mentioning. For policy purposes, the most important limitation is that we have treated programs as one homogenous category. In reality, programs differ -- by curriculum and length, for example. It is an important task for future research to investigate if and how rewards differ along such dimensions. 


\section{Appendix}

\section{Tables}

Table A1 Model estimates for random coefficient model year 2 and 3 after the training period. Swedish-born

\begin{tabular}{|c|c|c|c|c|c|c|}
\hline & \multicolumn{2}{|c|}{ Cohort 1} & \multicolumn{2}{|c|}{ Cohort 2} & \multicolumn{2}{|c|}{ Cohort 3} \\
\hline & 1987 & 1988 & 1990 & 1991 & 1993 & 1994 \\
\hline \multicolumn{7}{|l|}{ Earnings } \\
\hline Constant & $\begin{array}{l}4.528^{*} \\
(0.030)\end{array}$ & $\begin{array}{l}4.591^{*} \\
(0.030)\end{array}$ & $\begin{array}{l}4.582^{*} \\
(0.028)\end{array}$ & $\begin{array}{l}4.564 * \\
(0.031)\end{array}$ & $\begin{array}{l}4.223^{*} \\
(0.062)\end{array}$ & $\begin{array}{l}4.315^{*} \\
(0.059)\end{array}$ \\
\hline Age (26-45) & $\begin{array}{c}0.002 \\
(0.032)\end{array}$ & $\begin{array}{c}0.024 \\
(0.031)\end{array}$ & $\begin{array}{l}0.091^{*} \\
(0.029)\end{array}$ & $\begin{array}{l}0.079 * \\
(0.032)\end{array}$ & $\begin{array}{c}0.006 \\
(0.052)\end{array}$ & $\begin{array}{c}0.031 \\
(0.050)\end{array}$ \\
\hline Age (46-55) & $\begin{array}{c}0.023 \\
(0.049)\end{array}$ & $\begin{array}{c}0.010 \\
(0.047)\end{array}$ & $\begin{array}{c}0.1134 * \\
(0.042)\end{array}$ & $\begin{array}{c}0.052 \\
(0.048)\end{array}$ & $\begin{array}{c}0.093 \\
(0.072)\end{array}$ & $\begin{array}{l}0.116^{*} \\
(0.069)\end{array}$ \\
\hline Male & $\begin{array}{l}0.169^{*} \\
(0.030)\end{array}$ & $\begin{array}{l}0.208^{*} \\
(0.029)\end{array}$ & $\begin{array}{l}0.219^{*} \\
(0.027)\end{array}$ & $\begin{array}{l}0.162^{*} \\
(0.030)\end{array}$ & $\begin{array}{l}-0.038 \\
(0.046)\end{array}$ & $\begin{array}{l}-0.016 \\
(0.044)\end{array}$ \\
\hline High school & $\begin{array}{l}-0.001 \\
(0.032)\end{array}$ & $\begin{array}{l}-0.019 \\
(0.031)\end{array}$ & $\begin{array}{l}0.049^{*} \\
(0.029)\end{array}$ & $\begin{array}{l}-0.023 \\
(0.032)\end{array}$ & $\begin{array}{c}0.042 \\
(0.054)\end{array}$ & $\begin{array}{c}0.021 \\
(0.052)\end{array}$ \\
\hline College & $\begin{array}{c}0.026 \\
(0.055) \\
\end{array}$ & $\begin{array}{r}0.032 \\
(0.054) \\
\end{array}$ & $\begin{array}{c}-0.010 \\
(0.045) \\
\end{array}$ & $\begin{array}{c}-0.040 \\
(0.049) \\
\end{array}$ & $\begin{array}{l}0.329^{*} \\
(0.072) \\
\end{array}$ & $\begin{array}{l}0.260 * \\
(0.068) \\
\end{array}$ \\
\hline \multicolumn{7}{|l|}{ Reward } \\
\hline Constant & $\begin{array}{c}-2.082^{*} \\
(0.156)\end{array}$ & $\begin{array}{l}-2.120^{*} \\
(0.157)\end{array}$ & $\begin{array}{c}-1.655^{*} \\
(0.137)\end{array}$ & $\begin{array}{c}-1.743^{*} \\
(0.139)\end{array}$ & $\begin{array}{l}-2.734 * \\
(0.227)\end{array}$ & $\begin{array}{c}-2.778^{*} \\
(0.227)\end{array}$ \\
\hline Age $(26-45)$ & $\begin{array}{l}0.375^{*} \\
(0.105)\end{array}$ & $\begin{array}{c}0.276^{*} \\
(0.108)\end{array}$ & $\begin{array}{c}0.085 \\
(0.096)\end{array}$ & $\begin{array}{l}0.204^{*} \\
(0.090)\end{array}$ & $\begin{array}{l}0.489^{*} \\
(0.148)\end{array}$ & $\begin{array}{l}0.410^{*} \\
(0.159)\end{array}$ \\
\hline Age (46 - 55) & $\begin{array}{c}0.537^{*} \\
(0.154)\end{array}$ & $\begin{array}{c}0.462^{*} \\
(0.156)\end{array}$ & $\begin{array}{l}0.221^{*} \\
(0.126)\end{array}$ & $\begin{array}{l}0.324^{*} \\
(0.131)\end{array}$ & $\begin{array}{c}0.597^{*} \\
(0.200)\end{array}$ & $\begin{array}{l}0.433^{*} \\
(0.197)\end{array}$ \\
\hline Male & $\begin{array}{c}0.105 \\
(0.095)\end{array}$ & $\begin{array}{c}0.022 \\
(0.096)\end{array}$ & $\begin{array}{c}0.022 \\
(0.083)\end{array}$ & $\begin{array}{l}0.131^{*} \\
(0.087)\end{array}$ & $\begin{array}{l}0.396^{*} \\
(0.136)\end{array}$ & $\begin{array}{l}0.358^{*} \\
(0.135)\end{array}$ \\
\hline High school & $\begin{array}{l}0.749^{*} \\
(0.087)\end{array}$ & $\begin{array}{l}0.804^{*} \\
(0.086)\end{array}$ & $\begin{array}{l}0.650^{*} \\
(0.075)\end{array}$ & $\begin{array}{l}0.762^{*} \\
(0.080)\end{array}$ & $\begin{array}{l}0.803^{*} \\
(0.118)\end{array}$ & $\begin{array}{l}0.875^{*} \\
(0.117)\end{array}$ \\
\hline College & $\begin{array}{l}0.798 * \\
(0.133)\end{array}$ & $\begin{array}{l}0.961 * \\
(0.132)\end{array}$ & $\begin{array}{l}0.735 * \\
(0.104)\end{array}$ & $\begin{array}{l}0.750 * \\
(0.109)\end{array}$ & $\begin{array}{l}0.338^{*} \\
(0.206)\end{array}$ & $\begin{array}{l}0.417^{*} \\
(0.230)\end{array}$ \\
\hline \multicolumn{7}{|l|}{ Cost } \\
\hline Constant & $\begin{array}{c}0.676 \\
(0.655)\end{array}$ & $\begin{array}{c}0.894 \\
(0.743)\end{array}$ & $\begin{array}{c}-0.271 \\
(0.772)\end{array}$ & $\begin{array}{c}-0.285 \\
(0.538)\end{array}$ & $\begin{array}{l}-0.480 \\
(0.848)\end{array}$ & $\begin{array}{c}-0.296 \\
(1.229)\end{array}$ \\
\hline Age & $\begin{array}{l}0.138^{*} \\
(0.040)\end{array}$ & $\begin{array}{l}0.125^{*} \\
(0.045)\end{array}$ & $\begin{array}{l}0.189^{*} \\
(0.048)\end{array}$ & $\begin{array}{l}0.189^{*} \\
(0.033)\end{array}$ & $\begin{array}{l}0.250^{*} \\
(0.050)\end{array}$ & $\begin{array}{l}0.238^{*} \\
(0.074)\end{array}$ \\
\hline $\mathrm{Age}^{2}$ & $\begin{array}{c}-0.002 * \\
(0.001)\end{array}$ & $\begin{array}{l}-0.001 * \\
(0.001)\end{array}$ & $\begin{array}{l}-0.002^{*} \\
(0.001)\end{array}$ & $\begin{array}{l}-0.002 * \\
(0.001)\end{array}$ & $\begin{array}{c}-0.003 * \\
(0.001)\end{array}$ & $\begin{array}{c}-0.003 * \\
(0.001)\end{array}$ \\
\hline Male & $\begin{array}{l}1.019^{*} \\
(0.076)\end{array}$ & $\begin{array}{l}1.005^{*} \\
(0.077)\end{array}$ & $\begin{array}{l}0.927^{*} \\
(0.070)\end{array}$ & $\begin{array}{l}0.983^{*} \\
(0.071)\end{array}$ & $\begin{array}{l}0.695^{*} \\
(0.113)\end{array}$ & $\begin{array}{l}0.706^{*} \\
(0.113)\end{array}$ \\
\hline City & $\begin{array}{l}-0.025 \\
(0.070)\end{array}$ & $\begin{array}{c}-0.058 \\
(0.073)\end{array}$ & $\begin{array}{c}0.028 \\
(0.068)\end{array}$ & $\begin{array}{c}0.023 \\
(0.070)\end{array}$ & $\begin{array}{c}0.124 \\
(0.102)\end{array}$ & $\begin{array}{c}0.082 \\
(0.103)\end{array}$ \\
\hline Unemployed & $\begin{array}{l}0.002 * \\
(0.001) \\
\end{array}$ & $\begin{array}{l}0.002 * \\
(0.001)\end{array}$ & $\begin{array}{l}0.005 * \\
(0.001)\end{array}$ & $\begin{array}{l}0.006 * \\
(0.001)\end{array}$ & $\begin{array}{l}0.003 * \\
(0.001)\end{array}$ & $\begin{array}{l}0.003 * \\
(0.001)\end{array}$ \\
\hline \multicolumn{7}{|l|}{ Variance } \\
\hline$\sigma_{\varepsilon}^{2}$ & $\begin{array}{l}1.544 * \\
(0.157)\end{array}$ & $\begin{array}{l}1.600 * \\
(0.168)\end{array}$ & $\begin{array}{l}1.359 * \\
(0.126)\end{array}$ & $\begin{array}{l}1.381 * \\
(0.124)\end{array}$ & $\begin{array}{l}3.337 * \\
(0.348)\end{array}$ & $\begin{array}{l}3.249 * \\
(0.347)\end{array}$ \\
\hline$\sigma_{u}^{2}$ & $\begin{array}{l}0.404^{*} \\
(0.017)\end{array}$ & $\begin{array}{l}0.374^{*} \\
(0.016)\end{array}$ & $\begin{array}{l}0.333^{*} \\
(0.015)\end{array}$ & $\begin{array}{l}0.410^{*} \\
(0.019)\end{array}$ & $\begin{array}{l}0.835^{*} \\
(0.040)\end{array}$ & $\begin{array}{l}0.725^{*} \\
(0.041)\end{array}$ \\
\hline$\sigma_{\varepsilon u}$ & $\begin{array}{c}-0.252^{*} \\
(0.046)\end{array}$ & $\begin{array}{c}-0.223^{*} \\
(0.046)\end{array}$ & $\begin{array}{l}-0.284^{*} \\
(0.037)\end{array}$ & $\begin{array}{c}-0.328^{*} \\
(0.042)\end{array}$ & $\begin{array}{c}-0.653^{*} \\
(0.101)\end{array}$ & $\begin{array}{c}-0.549^{*} \\
(0.095)\end{array}$ \\
\hline Log-likelihood & -3869.87 & -3820.84 & -3721.37 & -4023.77 & -4030.19 & -4035.91 \\
\hline
\end{tabular}

Note: * indicates significance at the 5\% level. Asymptotic standard errors are within parentheses. 
Table A2a Model estimates for random coefficient model year 2 and 3 after the training period. Foreign-born

\begin{tabular}{|c|c|c|c|c|c|c|}
\hline & \multicolumn{2}{|c|}{ Cohort 1} & \multicolumn{2}{|c|}{ Cohort 2} & \multicolumn{2}{|c|}{ Cohort 3} \\
\hline & 1987 & 1988 & 1990 & 1991 & 1993 & 1994 \\
\hline \multicolumn{7}{|l|}{ Earnings } \\
\hline \multirow[t]{2}{*}{ Constant } & $4.523 *$ & $4.521^{*}$ & $4.479^{*}$ & $4.372 *$ & $4.038^{*}$ & $3.943^{*}$ \\
\hline & $(0.070)$ & $(0.067)$ & $(0.073)$ & $(0.082)$ & $(0.085)$ & $(0.097)$ \\
\hline \multirow[t]{2}{*}{ Age (26 - 45) } & $-0.044 *$ & 0.026 & $0.120^{*}$ & 0.075 & -0.021 & -0.093 \\
\hline & $(0.014)$ & $(0.035)$ & $(0.043)$ & $(0.052)$ & $(0.056)$ & $(0.072)$ \\
\hline \multirow[t]{2}{*}{ Age (46 - 55) } & 0.045 & 0.069 & $0.119^{*}$ & $0.140^{*}$ & 0.089 & -0.037 \\
\hline & $(0.057)$ & $(0.053)$ & $(0.059)$ & $(0.066)$ & $(0.080)$ & $(0.089)$ \\
\hline \multirow[t]{2}{*}{ Male } & $0.067 *$ & $0.141^{*}$ & 0.036 & -0.042 & -0.016 & -0.003 \\
\hline & $(0.037)$ & $(0.034)$ & $(0.036)$ & $(0.040)$ & $(0.047)$ & $(0.052)$ \\
\hline \multirow[t]{2}{*}{ High school } & -0.008 & -0.031 & 0.034 & -0.029 & 0.087 & 0.034 \\
\hline & $(0.038)$ & $(0.037)$ & $(0.037)$ & $(0.041)$ & $(0.052)$ & $(0.057)$ \\
\hline \multirow[t]{2}{*}{ College } & -0.004 & 0.111 & 0.033 & 0.042 & $0.383^{*}$ & $0.425^{*}$ \\
\hline & $(0.075)$ & $(0.071)$ & $(0.066)$ & $(0.072)$ & $(0.074)$ & $(0.080)$ \\
\hline \multicolumn{7}{|l|}{ Reward } \\
\hline \multirow[t]{2}{*}{ Constant } & $-2.288 *$ & $-2.371 *$ & $-2.330^{*}$ & $-2.157 *$ & $-2.698 *$ & $-2.197 *$ \\
\hline & $(0.086)$ & $(0.124)$ & $(0.157)$ & $(0.188)$ & $(0.172)$ & $(0.231)$ \\
\hline \multirow[t]{2}{*}{ Age (26 - 45) } & $0.392 *$ & $0.175^{*}$ & $0.148^{*}$ & $0.182^{*}$ & $0.311^{*}$ & $0.308^{*}$ \\
\hline & $(0.167)$ & $(0.060)$ & $(0.066)$ & $(0.113)$ & $(0.098)$ & $(0.164)$ \\
\hline \multirow{2}{*}{ Age (46 - 55) } & $0.243 *$ & 0.146 & 0.098 & 0.174 & 0.220 & 0.176 \\
\hline & $(0.124)$ & $(0.127)$ & $(0.134)$ & $(0.142)$ & $(0.200)$ & $(0.197)$ \\
\hline \multirow[t]{2}{*}{ Male } & 0.044 & -0.049 & 0.119 & 0.074 & -0.161 & -0.042 \\
\hline & $(0.084)$ & $(0.084)$ & $(0.086)$ & $(0.091)$ & $(0.126)$ & $(0.124)$ \\
\hline \multirow{2}{*}{ High school } & $0.680^{*}$ & $0.835^{*}$ & $0.622 *$ & $0.737^{*}$ & $0.619^{*}$ & $0.542 *$ \\
\hline & $(0.069)$ & $(0.067)$ & $(0.072)$ & $(0.078)$ & $(0.134)$ & $(0.129)$ \\
\hline \multirow[t]{2}{*}{ College } & $0.501 *$ & $0.544^{*}$ & $0.654^{*}$ & $0.668^{*}$ & -0.196 & -0.259 \\
\hline & $(0.149)$ & $(0.150)$ & $(0.122)$ & $(0.132)$ & $(0.271)$ & $(0.260)$ \\
\hline \multicolumn{7}{|l|}{ Cost } \\
\hline \multirow[t]{2}{*}{ Constant } & 1.205 & 1.174 & -0.008 & 0.148 & 0.948 & 0.474 \\
\hline & $(2.377)$ & $(1.286)$ & $(0.797)$ & $(0.786)$ & (1.947) & $(1.221)$ \\
\hline \multirow[t]{2}{*}{ Age } & 0.143 & $0.149 *$ & $0.225^{*}$ & $0.218^{*}$ & 0.166 & $0.195^{*}$ \\
\hline & $(0.144)$ & $(0.078)$ & $(0.048)$ & $(0.046)$ & $(0.116)$ & $(0.072)$ \\
\hline \multirow[t]{2}{*}{$\mathrm{Age}^{2}$} & -0.002 & -0.002 & $-0.003 *$ & $-0.003 *$ & -0.002 & $-0.002 *$ \\
\hline & $(0.002)$ & $(0.001)$ & $(0.001)$ & $(0.001)$ & $(0.002)$ & $(0.001)$ \\
\hline Male & $1.095^{*}$ & $1.040^{*}$ & $0.882 *$ & $0.895^{*}$ & $1.162 *$ & $1.182 *$ \\
\hline & $(0.078)$ & $(0.079)$ & $(0.079)$ & $(0.081)$ & $(0.118)$ & $(0.115)$ \\
\hline City & -0.045 & -0.065 & -0.033 & -0.078 & $0.343^{*}$ & $0.200^{*}$ \\
\hline & $(0.061)$ & $(0.060)$ & $(0.063)$ & $(0.066)$ & $(0.089)$ & $(0.090)$ \\
\hline Unemployed & $0.005^{*}$ & $0.005^{*}$ & $0.006^{*}$ & $0.007 *$ & $0.007 *$ & $0.009 *$ \\
\hline & $(0.001)$ & $(0.001)$ & $(0.001)$ & $(0.001)$ & $(0.001)$ & $(0.002)$ \\
\hline Variance & & & & & & \\
\hline$\sigma_{\varepsilon}^{2}$ & $2.583 *$ & $2.556^{*}$ & $2.506^{*}$ & $2.672 *$ & $6.138^{*}$ & $5.838^{*}$ \\
\hline & $(0.069)$ & $(0.138)$ & $(0.151)$ & $(0.169)$ & $(0.382)$ & $(0.363)$ \\
\hline$\sigma_{u}^{2}$ & $0.609 *$ & $0.531^{*}$ & $0.595^{*}$ & $0.760^{*}$ & $1.073^{*}$ & $1.379 *$ \\
\hline & $(0.035)$ & $(0.030)$ & $(0.033)$ & $(0.040)$ & $(0.056)$ & $(0.074)$ \\
\hline$\sigma_{\varepsilon u}$ & $-0.763 *$ & $-0.688^{*}$ & $-0.678^{*}$ & $-0.840^{*}$ & $-1.410 *$ & $-1.779 *$ \\
\hline $\mathrm{gu}$ & $(0.063)$ & $(0.059)$ & $(0.061)$ & $(0.072)$ & $(0.131)$ & $(0.142)$ \\
\hline Log-likelihood & -5363.4322 & -5166.4741 & -5492.8550 & -5631.0375 & -6169.0407 & -6292.2393 \\
\hline
\end{tabular}

Note: * indicates significance at the 5\% level. Asymptotic standard errors are within parentheses. 
Table A2b Extended variable specification of reward equation for foreign-born people

\begin{tabular}{|c|c|c|c|c|c|c|}
\hline & \multicolumn{2}{|c|}{ Cohort $1(84 / 85)$} & \multicolumn{2}{|c|}{ Cohort $2(87 / 88)$} & \multicolumn{2}{|c|}{ Cohort $3(90 / 91)$} \\
\hline Variables & 1986 & 1987 & 1990 & 1991 & 1993 & 1994 \\
\hline \multicolumn{2}{|c|}{ Years in Sweden } & & \multicolumn{2}{|l|}{ Earnings } & & \\
\hline \multirow[t]{2}{*}{$6-10$} & $-0.155^{*}$ & $-0.130 *$ & $-0.123 *$ & -0.104 & -0.102 & 0.043 \\
\hline & $(0.066)$ & $(0.064)$ & $(0.068)$ & $(0.074)$ & $(0.076)$ & $(0.083)$ \\
\hline \multirow[t]{2}{*}{$11-$} & -0.089 & -0.080 & 0.032 & 0.068 & -0.100 & 0.056 \\
\hline & $(0.063)$ & $(0.060)$ & $(0.062)$ & $(0.068)$ & $(0.067)$ & $(0.073)$ \\
\hline \multicolumn{7}{|l|}{ Origin } \\
\hline \multirow[t]{2}{*}{ Northen E. } & -0.037 & -0.030 & -0.098 & -0.088 & -0.032 & -0.030 \\
\hline & $(0.060)$ & $(0.059)$ & $(0.063)$ & $(0.069)$ & $(0.085)$ & $(0.091)$ \\
\hline \multirow[t]{2}{*}{ Eastern E. } & $-0.149 *$ & $-0.132 *$ & $-0.161 *$ & $-0.192 *$ & -0.233 & $-0.464 *$ \\
\hline & $(0.063)$ & $(0.060)$ & $(0.060)$ & $(0.065)$ & $(0.816)$ & $(0.090)$ \\
\hline \multirow[t]{2}{*}{ Southern E. } & $-0.181^{*}$ & $-0.125^{*}$ & $-0.205^{*}$ & $-0.285^{*}$ & -0.078 & $-0.275^{*}$ \\
\hline & $(0.054)$ & $(0.050)$ & $(0.059)$ & $(0.066)$ & $(0.814)$ & $(0.090)$ \\
\hline \multirow[t]{2}{*}{ Middle East } & $-0.271 *$ & $-0.255^{*}$ & $-0.374 *$ & $-0.263 *$ & $-0.326^{*}$ & $-0.468 *$ \\
\hline & $(0.062)$ & $(0.061)$ & $(0.061)$ & $(0.066)$ & $(0.067)$ & $(0.073)$ \\
\hline \multirow[t]{2}{*}{ Other } & $-0.202 *$ & $-0.139 *$ & $-0.156^{*}$ & $-0.159 *$ & $-0.274^{*}$ & $-0.436^{*}$ \\
\hline & $(0.070)$ & $(0.067)$ & $(0.064)$ & $(0.067)$ & $(0.072)$ & $(0.079)$ \\
\hline \multicolumn{3}{|c|}{ Years in Sweden } & Reward & & & \\
\hline \multirow[t]{2}{*}{$6-10$} & $0.688^{*}$ & $0.776^{*}$ & $0.591^{*}$ & $0.413 *$ & $0.507^{*}$ & $0.294 *$ \\
\hline & $(0.104)$ & $(0.103)$ & $(0.112)$ & $(0.120)$ & $(0.149)$ & $(0.151)$ \\
\hline \multirow[t]{2}{*}{$11-$} & $0.551 *$ & $0.689 *$ & $0.600^{*}$ & $0.430 *$ & $0.462 *$ & $0.274^{*}$ \\
\hline & $(0.093)$ & $(0.090)$ & $(0.100)$ & $(0.107)$ & $(0.137)$ & $(0.140)$ \\
\hline \multicolumn{7}{|l|}{ Origin } \\
\hline \multirow[t]{2}{*}{ Northen E. } & $0.562 *$ & $0.560 *$ & $0.677^{*}$ & $0.619 *$ & $0.507 *$ & $0.604 *$ \\
\hline & $(0.120)$ & $(0.124)$ & $(0.143)$ & $(0.151)$ & $(0.220)$ & $(0.217)$ \\
\hline \multirow[t]{2}{*}{ Eastern E. } & $0.758 *$ & $0.915^{*}$ & $0.735^{*}$ & $0.653 *$ & $0.741 *$ & $0.943 *$ \\
\hline & $(0.116)$ & $(0.113)$ & $(0.117)$ & $(0.126)$ & $(0.173)$ & $(0.176)$ \\
\hline \multirow[t]{2}{*}{ Southern E. } & $0.744^{*}$ & $0.679 *$ & $0.728^{*}$ & $0.810^{*}$ & $0.616^{*}$ & $0.559 *$ \\
\hline & $(0.107)$ & $(0.103)$ & $(0.125)$ & $(0.140)$ & $(0.204)$ & $(0.202)$ \\
\hline \multirow[t]{2}{*}{ Middle East } & $0.499 *$ & $0.682 *$ & $0.775^{*}$ & $0.812 *$ & $0.656^{*}$ & $0.722 *$ \\
\hline & $(0.113)$ & $(0.110)$ & $(0.114)$ & $(0.120)$ & $(0.145)$ & $(0.147)$ \\
\hline \multirow[t]{2}{*}{ Other } & $0.707^{*}$ & $0.742 *$ & $0.622 *$ & $0.705^{*}$ & $0.658 *$ & $0.860 *$ \\
\hline & $(0.113)$ & $(0.110)$ & $(0.114)$ & $(0.120)$ & $(0.151)$ & $(0.152)$ \\
\hline
\end{tabular}

Note: * indicates significance at the $5 \%$ level. Asymptotic standard errors are within parentheses. 


\section{References}

Ackum, S. (1991), "Youth Unemployment, Labor Market Programs and SubsequentEarnings", Scandinavian Journal of Economics 93, 531-43.

AMS (1995), "Den yrkesinriktade arbetsmarknadsutbildningens effekt på inkomst och sysselsättning”, Ubra 1995:1, National Labour Market Board Stockholm, Sweden.

Ashenfelter, O. (1978), "Estimating the Effect of Training Programs on Earnings", Review of Economics and Statistics 60, 47-57.

Axelsson, R. (1989). "Svensk Arbetsmarknadsutbildning - En kvantitativ analys av dess effekter", Umeå Economic Studies No. 197, University of Umeå, Sweden.

Björklund, A. and R. Moffitt, (1987), "The Estimation of Wage Gain and Welfare Gains in Self-Selection Models", Review of Economics and Statistics 69, 42-49.

Brännäs, K. and Eriksson, M (1996), "Enrolment in Labor Market Training Programs", Labour 10, 193-208.

Ds (2000:38), "En effektivare arbetsmarknadsutbildning", Ministry for Industry, Employment and Communications, Stockholm, Sweden.

Edin, P.A. (1988), "Individual Consequences of Plant Closure", PhD thesis, Department of Economics, Uppsala University, Sweden.

Eriksson, M. (1997), "To Choose or Not to Choose: Choice and Choice Set Models", Umeå Economic Studies No. 443. Umeå University, Sweden.

Friedlander, D., D. Greenberg, and P. Robins (1997), "Evaluating Government training Programs for the Economically Disadvantaged“, Journal of Economic Literature 35, 1809-1855.

Greene, W. (1993), Econometric Analysis, New York: Macmillan.

Heckman, J. (1990), "Varieties of Selection Bias", American Economic Review 80, 313318.

Heckamn, J., and B. Honore (1990), "The Empirical Content of the Roy Model", Econometrica 58, 1121-1149.

Heckman, J., J. LaLonde and J. Smith. (1998), "The Economics and Econometrics of Training Programs", Handbook of Labor Economics, Volume III, ed. by Orley Ashenfelter and David Card. Amsterdam: North Holland.

Heckman, J. and R. Robb (1985), "Alternative Methods for Evaluating the Impact of Interventions, an Overview", Journal of Econometrics 30, 239-267.

Heckman, J. and R. Robb (1986), "Alternative Methods for Solving the Problem of Selection Bias in Evaluating the Impact of Treatment on Outcome" in H. Wainer (ed.), Drawing Inference from Self-selected Samples, Berlin: Springer, 63-107.

Heckman, J. and J. Smith (1996), "Experimental and Non-experimental Evaluation" in International Handbook of Labor Market Policy and Evaluation, Ed. By Günther Schmid et al.

Heckman, J., and J. Smith (1999), "The Pre-program Earnings Dip and the Determinants of Participation in a Social Program: Implications for Simple Program Evaluations Strategies", Economic Journal 109, 313-348. 
Larsson, L. (2000), "Evaluation of youth labour market programmes", Working paper 2000:1, Institute for Labour Market Policy Evaluation, Uppsala.

Maddala, G. S (1983), "Limited Dependent and Qualitative Variables in Econometrics", Econometric Society Monographs No. 3.

Melkersson, M. (1999), "Explaining Choice Set Size for Unemployed", Applied Economics 31, 1599-1607.

OECD (1997), Employment Outlook, July 1997, Paris.

OECD (2000), Employment Outlook, June 2000, Paris.

Okeke, S. (2001), “Arbetsmarknadsutbildningen 1999”, URA 2001:7, National Labour Market Board, Stockholm.

Olli, Å. (1996), “Arbetsmarknadspolitiskt kalendarium”, EFA, Arbetsmarknads departementet.

Quandt, R. E. (1972), “A New Approach to Estimating Switching Regressions", Journal of the American Statistical Association 67, 306-10.

Regnér, H. (1993), "Choosing Among Alternative Non Experimental Methods for Estimating the Impact of Training: New Swedish Evidence", Report no 8, Swedish Institute for Social Research, Stockholm University.

Regnér, H. (1997), “Training at the Job and Training for a New Job: Two Swedish Studies", Swedish Institute for Social Research - Dissertation Series. Stockholm University.

Roy, A. D. (1951), "Some Thoughts on the Distribution of Earnings", Oxford Economic Papers 33, 679-685.

Vella, F., and M. Verbeek (1998), "Estimating and Interpreting Models with Endogenous Treatment Effects", Working paper, Tilburg University.

Willis, J. R (1986), "Wage Determinants: A Survey and Reinterpretation of Human Capital Earnings Functions", in Handbook of Labor Economics 1, Edited by O. Ashenfelter and R. Layard.

Zetterberg, J. (1997), "Effekter av arbetsmarknadspolitik - en översikt av svensk empirisk forskning". Bilaga till Arbetsmarknadspolitiska kommittén.

Åtgärdsundersökning (1998), "En uppföljning av deltagare som avslutat konjunkturberoende åtgärd fjärde kvartalet 1996", Apra 1998:3, National Labour Market Board, Stockholm. 


\section{IZA Discussion Papers}

\begin{tabular}{|c|c|c|c|c|}
\hline No. & Author(s) & Title & Area & Date \\
\hline 587 & $\begin{array}{l}\text { H. Bonin } \\
\text { W. Kempe } \\
\text { H. Schneider }\end{array}$ & $\begin{array}{l}\text { Kombilohn oder Workfare? Zur Wirksamkeit } \\
\text { zweier arbeitsmarktpolitischer Strategien }\end{array}$ & 3 & 09/02 \\
\hline 588 & M. Frölich & $\begin{array}{l}\text { Nonparametric IV Estimation of Local Average } \\
\text { Treatment Effects with Covariates }\end{array}$ & 6 & 09/02 \\
\hline 589 & $\begin{array}{l}\text { S. Jurajda } \\
\text { K. Terrell }\end{array}$ & $\begin{array}{l}\text { Job Growth in Early Transition: Comparing Two } \\
\text { Paths }\end{array}$ & 4 & $09 / 02$ \\
\hline 590 & $\begin{array}{l}\text { H. Görg } \\
\text { E. Strobl } \\
\text { F. Walsh }\end{array}$ & $\begin{array}{l}\text { Why Do Foreign-Owned Firms Pay More? } \\
\text { The Role of On-the-Job Training }\end{array}$ & 2 & $10 / 02$ \\
\hline 591 & $\begin{array}{l}\text { H. Görg } \\
\text { E. Strobl }\end{array}$ & $\begin{array}{l}\text { Spillovers From Foreign Firms Through Worker } \\
\text { Mobility: An Empirical Investigation }\end{array}$ & 1 & $10 / 02$ \\
\hline 592 & J. Wagner & $\begin{array}{l}\text { Testing Lazear's Jack-of-All-Trades View of } \\
\text { Entrepreneurship with German Micro Data }\end{array}$ & 5 & $10 / 02$ \\
\hline 593 & $\begin{array}{l}\text { T. K. Bauer } \\
\text { P. J. Dross } \\
\text { J. P. Haisken-DeNew }\end{array}$ & Sheepskin Effects in Japan & 1 & $10 / 02$ \\
\hline 594 & $\begin{array}{l}\text { S. C. Wolter } \\
\text { M. Coradi Vellacott }\end{array}$ & $\begin{array}{l}\text { Sibling Rivalry: A Look at Switzerland with } \\
\text { PISA Data }\end{array}$ & 2 & $10 / 02$ \\
\hline 595 & $\begin{array}{l}\text { W. Arulampalam } \\
\text { A. L. Booth } \\
\text { M. L. Bryan }\end{array}$ & $\begin{array}{l}\text { Work-Related Training and the New National } \\
\text { Minimum Wage in Britain }\end{array}$ & 3 & $10 / 02$ \\
\hline 596 & $\begin{array}{l}\text { H. Görg } \\
\text { E. Strobl }\end{array}$ & $\begin{array}{l}\text { Relative Wages, Openness and Skill-Biased } \\
\text { Technological Change }\end{array}$ & 2 & $10 / 02$ \\
\hline 597 & $\begin{array}{l}\text { S. M. Fuess, Jr. } \\
\text { M. Millea }\end{array}$ & $\begin{array}{l}\text { Disentangling Pay and Productivity in a } \\
\text { Corporatist Economy: The Case of Germany }\end{array}$ & 5 & $10 / 02$ \\
\hline 598 & $\begin{array}{l}\text { D. Del Boca } \\
\text { A. Lusardi }\end{array}$ & $\begin{array}{l}\text { Credit Market Constraints and Labor Market } \\
\text { Decisions }\end{array}$ & 2 & $10 / 02$ \\
\hline 599 & $\begin{array}{l}\text { H. N. Mocan } \\
\text { B. Scafidi } \\
\text { E. Tekin }\end{array}$ & Catholic Schools and Bad Behavior & 5 & $10 / 02$ \\
\hline 600 & $\begin{array}{l}\text { J. S. Lauerová } \\
\text { K. Terrell }\end{array}$ & $\begin{array}{l}\text { Explaining Gender Differences in Unemployment } \\
\text { with Micro Data on Flows in Post-Communist } \\
\text { Economies }\end{array}$ & 4 & $10 / 02$ \\
\hline 601 & $\begin{array}{l}\text { Š. Jurajda } \\
\text { K. Terrell }\end{array}$ & $\begin{array}{l}\text { What Drives the Speed of Job Reallocation } \\
\text { During Episodes of Massive Adjustment? }\end{array}$ & 5 & $10 / 02$ \\
\hline 602 & L. Locher & Migration in the Soviet Successor States & 2 & $10 / 02$ \\
\hline 603 & $\begin{array}{l}\text { T. Andrén } \\
\text { B. Gustafsson }\end{array}$ & $\begin{array}{l}\text { Income Effects from Labor Market Training } \\
\text { Programs in Sweden During the 80's and 90's }\end{array}$ & 2 & $10 / 02$ \\
\hline
\end{tabular}

